\title{
Light-Driven Biocatalysis in Liposomes and Polymersomes: Where Are We Now?
}

\author{
Guoshu Wang and Kathrin Castiglione *(1) \\ Institute of Bioprocess Engineering, Friedrich-Alexander University Erlangen-Nürnberg, 91052 Erlangen, Germany; \\ guoshu.wang@fau.de \\ * Correspondence: kathrin.castiglione@fau.de
}

Received: 1 December 2018; Accepted: 20 December 2018; Published: 25 December 2018

check for

updates

\begin{abstract}
The utilization of light energy to power organic-chemical transformations is a fundamental strategy of the terrestrial energy cycle. Inspired by the elegance of natural photosynthesis, much interdisciplinary research effort has been devoted to the construction of simplified cell mimics based on artificial vesicles to provide a novel tool for biocatalytic cascade reactions with energy-demanding steps. By inserting natural or even artificial photosynthetic systems into liposomes or polymersomes, the light-driven proton translocation and the resulting formation of electrochemical gradients have become possible. This is the basis for the conversion of photonic into chemical energy in form of energy-rich molecules such as adenosine triphosphate (ATP), which can be further utilized by energy-dependent biocatalytic reactions, e.g., carbon fixation. This review compares liposomes and polymersomes as artificial compartments and summarizes the types of light-driven proton pumps that have been employed in artificial photosynthesis so far. We give an overview over the methods affecting the orientation of the photosystems within the membranes to ensure a unidirectional transport of molecules and highlight recent examples of light-driven biocatalysis in artificial vesicles. Finally, we summarize the current achievements and discuss the next steps needed for the transition of this technology from the proof-of-concept status to preparative applications.
\end{abstract}

Keywords: light-driven catalysis; artificial vesicle; liposome; polymersome; proton pump

\section{Introduction}

Due to the steadily increasing global energy demand, the rapid depletion of fossil fuels, and the growing level of environmental awareness, alternative concepts for the synthesis of chemical products have to be driven forward. In this context, there is much interest in developing catalytic processes that make use of the almost infinite solar energy. The conversion of photonic to chemical energy by photosynthesis is the basis for the majority of life on Earth as we know it and artificial photosynthetic systems can truly be described as "biomimetic". The mimicry of natural strategies for the conversion of energy-depleted molecules, most importantly adenosine diphosphate (ADP) and the oxidized nicotinamide cofactors $\mathrm{NAD}(\mathrm{P})^{+}$, into their energized counterparts adenosine triphosphate (ATP) and $\mathrm{NAD}(\mathrm{P}) \mathrm{H}$ is highly interesting for energy-demanding enzymatic cascade reactions and, in particular, for carbon-fixation. The utilization of carbon dioxide $\left(\mathrm{CO}_{2}\right)$ as feedstock is of high relevance for the development of sustainable "green" production processes of organic compounds and is paving the way to a bio-based chemical industry [1].

In order to reap the full benefits of photosynthesis, the compartmentalization of cells has to be mimicked since the light-induced formation of electrochemical gradients across membranes is the crucial natural strategy of cells to harness the photonic energy. As such artificial compartments, vesicles derived from lipids (liposomes) or polymers (polymersomes) have drawn intensive attention [2,3]. In this review, we compare liposomes and polymersomes as compartments for the utilization of light as an energy form 
for biocatalysis and give an overview of light-driven proton-pumps that can be used as tools for the generation of the corresponding proton gradients. In addition, we summarize the approaches that have been developed to control the orientation of the membrane proteins within the artificial membranes and review the application examples of the vesicle-based biocatalysis powered by light.

\section{Comparison of Liposomes and Polymersomes as Artificial Compartments}

\subsection{General Properties of Liposomes}

Liposomes are self-assembling spherical vesicles consisting of natural biological lipids or of synthetic alternatives. As a simplified mimicry of membrane-surrounded natural cell compartments, liposomes have been of great interest for researchers and have been well studied since the 1960s [4]. Depending on the preparation method, liposomes can be generated that fall into different size categories, i.e., small unilamellar vesicles (20-100 nm), large unilamellar vesicles $(100 \mathrm{~nm}-1 \mu \mathrm{m})$, and giant unilamellar vesicles $(>1 \mu \mathrm{m})$ [2]. In addition, multilamellar vesicles consisting of concentric lipid bilayers analogous to onion layers can be produced that have typical diameters of several micrometers.

\subsection{Major Fields of Application of Liposomes}

The tunable size and lipid composition in combination with the possibilities to embed membrane proteins into the bilayers and to encapsulate materials in the vesicle lumen are the basis for the versatile use of liposomes in diverse fields of application. Amongst many others, they have been used as delivery vehicles for drugs (see review [5]), dermal carriers in cosmetics (see review [6]), functional compound carriers in food technology (see review [7]) and nano-vesicles to profile lipid-protein interactions in proteomics [8-10]. In particular, the high biocompatibility of lipid bilayers has paved the way to embed membrane proteins into the membrane of liposomes, which opens up the possibilities of spatially separating cascade reaction steps and using liposomes as artificial reaction compartments (see review [11]).

\subsection{Functionalization of Liposomes for Light-Driven Biocatalysis}

Many research groups were inspired to embed different photosynthetic systems into the membrane of liposomes to convert light energy into ATP and to employ liposomes for light-driven biocatalysis [12-20]. In those studies, different phospholipids were used to mimic the transversal heterogeneity of a natural asymmetric membrane, which is composed of an outer layer (with the lipids phosphatidylcholine and sphingomyelin) and an inner layer (with the lipids phosphatidylethanolamine, phosphatidylserine and phosphatidylinositol) [21,22]. Subsequently, an asymmetric charge distribution occurs across the bilayer, with higher negative charge in the inner layer typically due to phosphatidylserine. This chemical property facilitates the correct orientation of many transmembrane proteins which carry a positive charge on their cytosolic domain [23-25]. To imitate this physiology of natural membranes, different mixtures of lipids were used. Table 1 gives an overview of the liposome-based photosynthetic systems that have been established so far and of the employed lipid mixtures. In most cases, lipids belonging to the class of phosphatidylcholines (PC) have been used, which are either employed as a molecule mixture (most commonly derived from natural sources such as egg yolk or soybeans) or as pure compounds, e.g., in form of 1,2-dioleoyl-sn-glycero-3-phosphocholine (DOPC). Likewise, phosphatidic acid (PA) and phosphatidylethanolamine (PE) represent mixtures of lipids with the same headgroup but varying (saturated or unsaturated) acyl chains. The structures of lipids that were used in pure form are shown in Figure 1 (phosphatidylcholines) and Figure 2 (other lipids). Due to the poor stability of liposomes, looking for more stable alternatives has become a new trend in recent years and polymersomes are emerging as most promising alternative vesicle type [26,27]. 


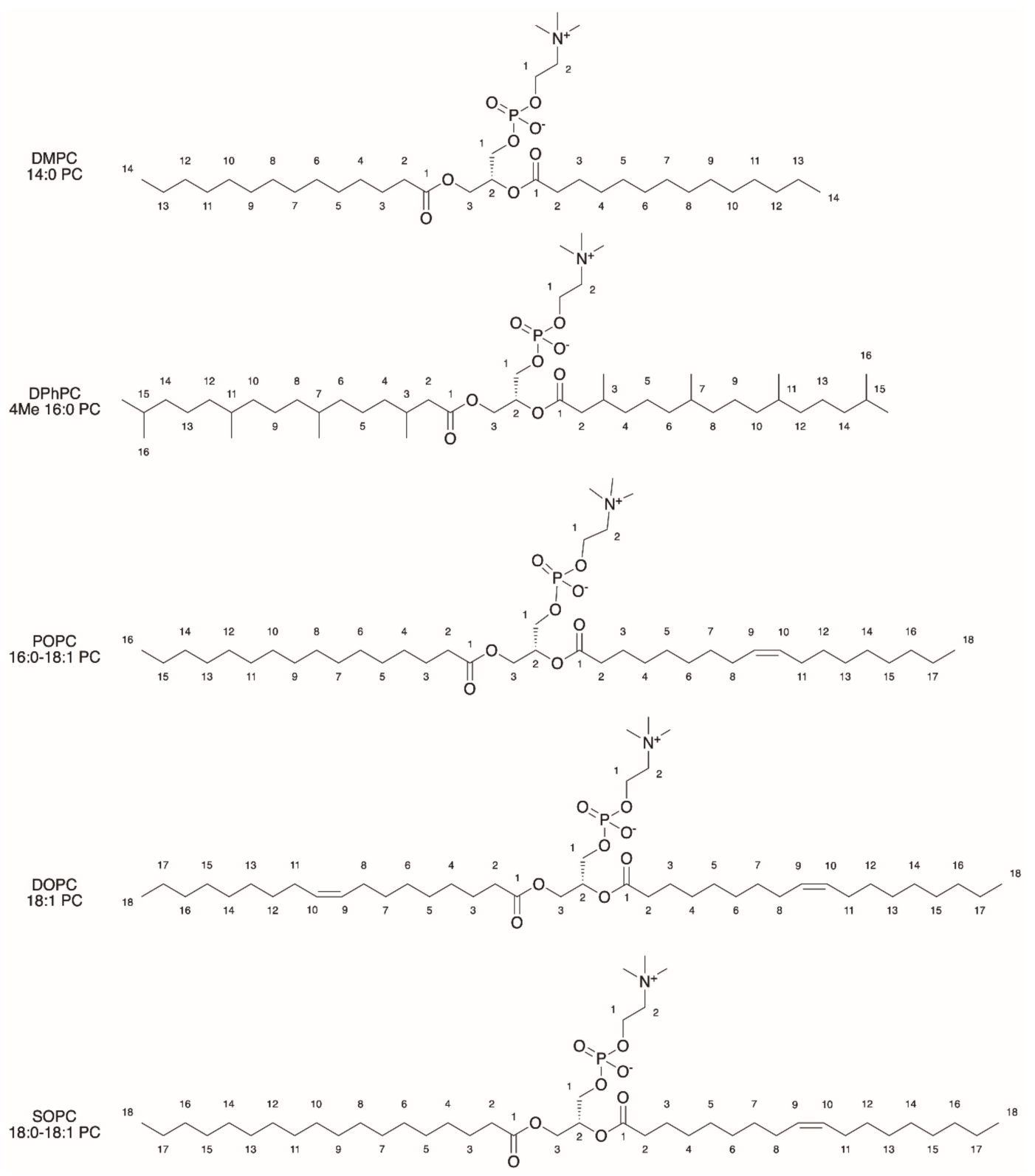

Figure 1. Structures of phosphatidylcholines that were used for the generation of liposomes with photosynthetic activity. Abbreviations are listed in the footnote of Table 1. Below the common abbreviation of the lipids, an alternative name is presented that describes the fatty acid chains in a comprehensible manner, i.e., (number of carbons in the fatty acid chain): (number of double bonds in the fatty acid chain). Thus, 14:0 corresponds to 14 carbons in the fatty acid chain without any double bond. In case of two different fatty acid chains, the individual descriptions of the chains are separated by a dash. 

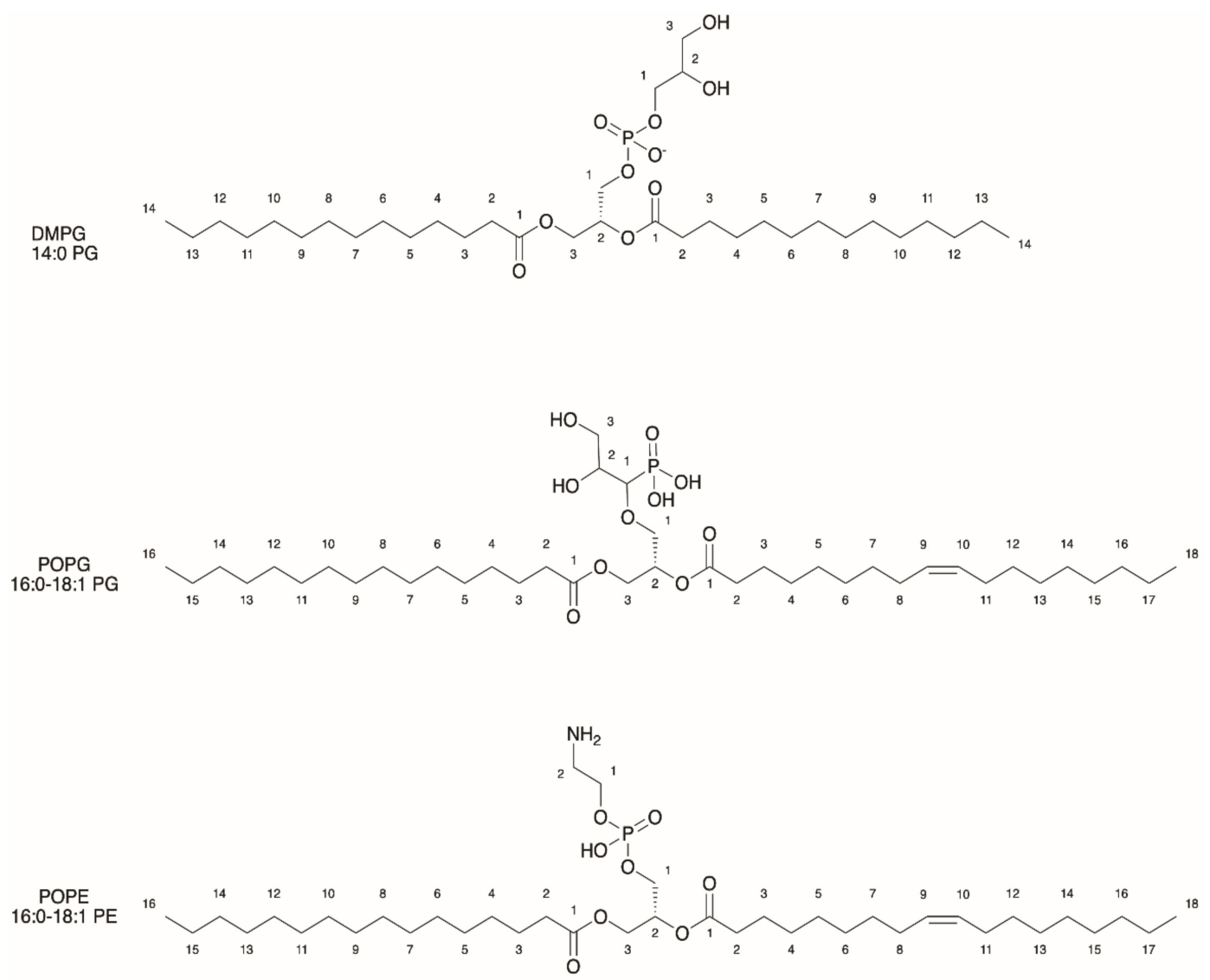

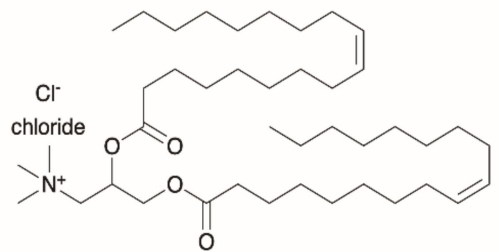

DOTAP

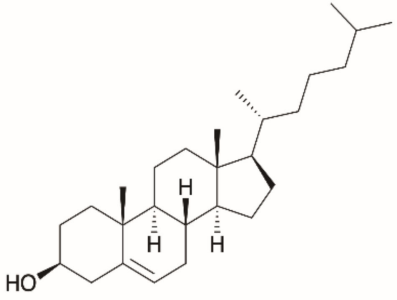

Cholesterol

Figure 2. Structures of further lipids (apart from phosphatidylcholines) that were used for the generation of liposomes with photosynthetic activity. Abbreviations are listed in the footnote of Table 1. The number-based nomenclature, which is given below the common abbreviation, is explained in the legend of Figure 1.

\subsection{General Properties of Polymersomes}

Polymersomes are also hollow spherical vesicles, but in contrast to their lipid-based counterparts they consist of self-assembling amphiphilic block copolymers [28]. The most common polymers used for polymersome formation are di- (AB-type) or tri-block copolymers (more commonly of the ABA-type, rarely of the ABC-type). A and C represent hydrophilic blocks whereas $B$ is hydrophobic.

\subsection{Major Fields of Application of Polymersomes}

Polymersome research focused mainly on targeted drug-delivery and diagnostic imaging [29,30], the de novo-design of artificial cells and the mimicry of organelles in synthetic biology [31,32], and the development of nanoreactors for enzymatic reactions [29,32-34]. 


\subsection{Advantages and Challenges of Using Polymersomes}

In comparison to liposomes, the significant advantages of polymersomes are their higher chemical and mechanical stability [35] as well as their lower permeability, which allows a tighter control over all mass transfer phenomena [36] (Figure 3, which also summarizes the main features of polymersomes and liposomes, e.g., encapsulation, lateral fluidity and chemical versatility). During the last decade, considerable effort has been devoted to the development of stimulus-responsive polymersomes for drug delivery, which decompose in response to environmental changes such as variations in $\mathrm{pH}$ or magnetic field, as reviewed recently [2]. For this purpose, the uncontrolled diffusion out of these vesicles has to be negligible. In the context of artificial photosynthesis, the lower permeability of the polymer membrane might also be of advantage because the ATP production per proton that is translocated by the light-driven proton pumps should be more efficient if the passive back-diffusion across the membrane is as low as possible. However, detailed comparative studies addressing this question are still lacking. The higher stability and lower permeability of polymersomes is mainly associated with their increased membrane thickness [37]. This raises problems for the functional integration of transmembrane proteins, which have been evolved to fit perfectly into natural lipid membranes with a typical thickness of 3-5 nm [38]. The main challenge in this context is the so-called hydrophobic mismatch, which is defined as the difference between the lengths of the hydrophobic transmembrane segment and of the hydrophobic membrane core $\left(\Delta d=d_{\text {membrane }}-d_{\text {protein }}\right)$ [39]. Nevertheless, the successful reconstitution of membrane proteins into polymer membranes has been demonstrated for several types of polymers (see Review [40]), but the functional integration is dependent on both, the nature of the polymer and the membrane thickness [41]. The polymer that has been used most extensively for the integration of membrane proteins, usually for the establishment of a highly selective mass transport into and out of the vesicles, is poly(2-methyloxazoline)-poly(dimethylsiloxane)-poly(2-methyloxazoline) (PMOXA-PDMS-PMOXA) [30,34,41-57]. In this case, the ability to accommodate membrane proteins easily and in functional form, is due to the high flexibility and high fluidity of the PDMS-based polymers $[41,58,59]$, as well as to their broad polydispersity $[60,61]$. These characteristics do not only allow sufficient lateral diffusion of the polymers to facilitate natural membrane protein functions, but also enable shorter polymers to aggregate at the integration point and allow membrane compression in the vicinity of the membrane proteins, which leads to a reduction of the energy penalty exerted by the hydrophobic mismatch. In case of PMOXA-PDMS-PMOXA membranes, hydrophobic mismatches of at least $7 \mathrm{~nm}$ are tolerated leading to functional reconstitutions of proteins into polymer membranes with a thickness of about $14 \mathrm{~nm}$ [41]. In contrast, for polyisobutylene-polyethylene glycol-polyisobutylene membranes (PIB-PEG-PIB) it has been demonstrated that a hydrophobic mismatch of 2 nm prevents the reconstitution of a channel protein in functional form [62]. 

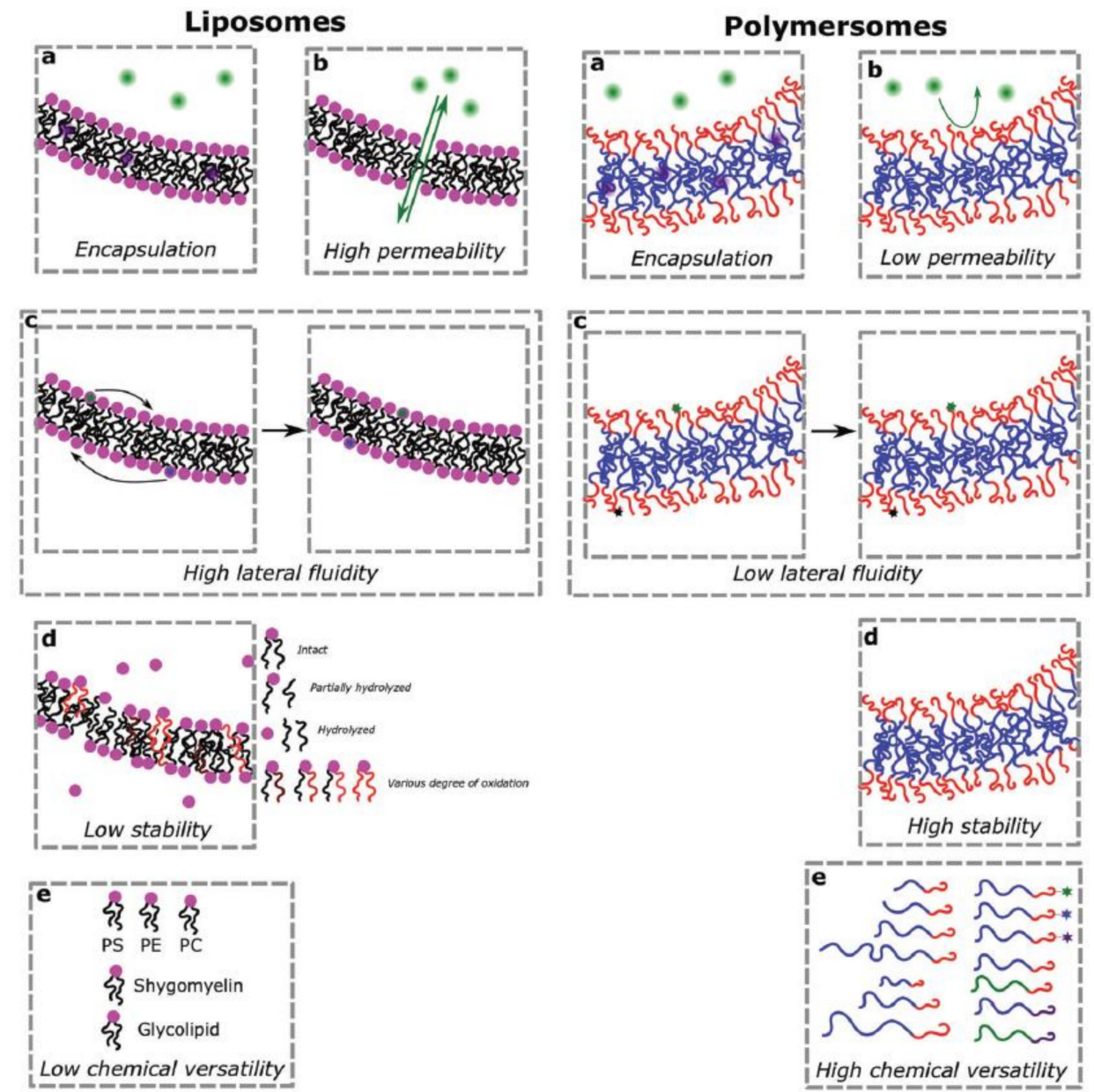

Figure 3. Properties comparison between liposomes and polymersomes [2]. Reproduced by permission of The Royal Society of Chemistry.

\subsection{Functionalization of Polymersomes for Light-Driven Biocatalysis}

Apart from functionalizing polymersome membranes for selective mass transport [34,63-69], efforts have been made to embed different photosynthetic elements into polymeric membranes to prepare polymersomes as artificial photosynthetic organelles, which are able to use light energy for ATP synthesis as well as to power downstream reactions [70-72]. Polymers, which have been employed specifically for light-driven biocatalysis and showed compatibility with the photosynthetic elements, are listed also in Table 1. Their chemical structures are shown in Figure 4. 
Table 1. List of studies which used liposomes and polymersomes for light-driven biocatalysis by embedding (artificial) photosynthetic systems.

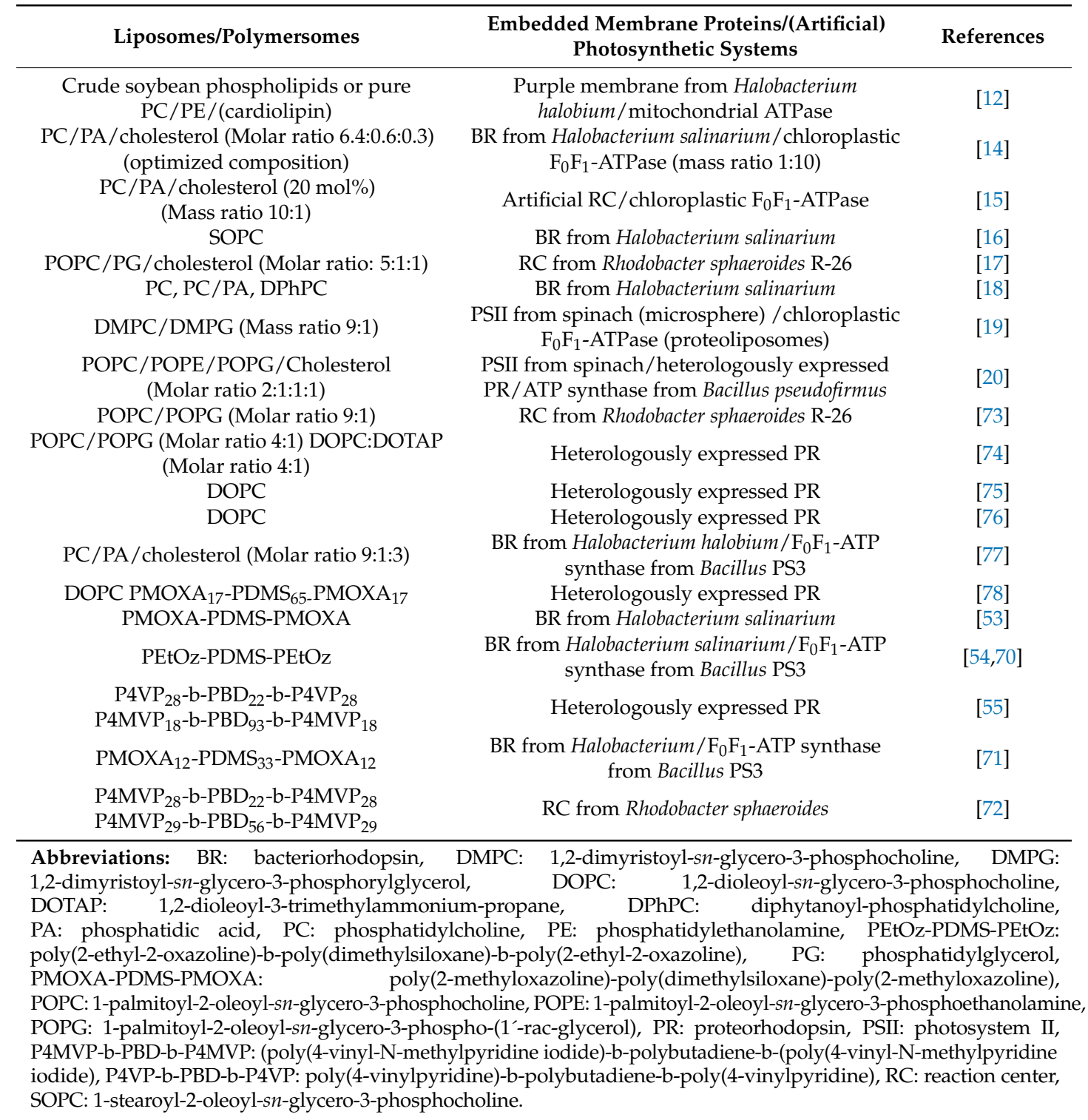


PMOXA $_{x}-$ PDMS $_{y}-$ PMOXA $_{x}$<smiles>[Y]C(C)(O)CCN(CC(C)(C)O[Si](C)(C)C)C(C)=O</smiles>

$\mathrm{PEtO}_{\mathrm{x}}-\mathrm{PDMS}_{\mathrm{y}}-\mathrm{PEtO}_{\mathrm{x}}$

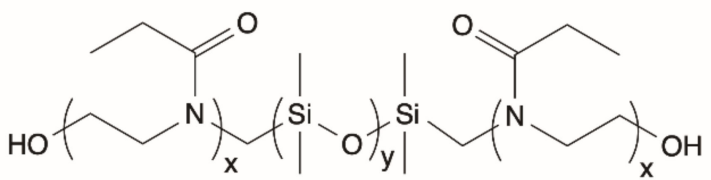

$P 4 V P_{x}-b-P B D_{y}-b-P 4 V P_{x}$

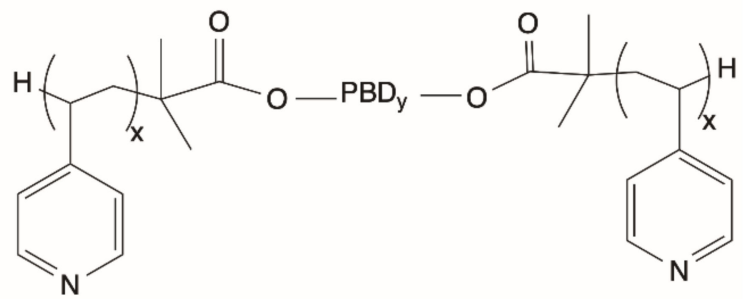

P4MVP $P_{x}-b-P B D_{y}-b-P 4 M V P_{x}$<smiles>[Y]C(C)C(C)(C)C(C)(C)C(=O)OC[R16](=O)OC(=O)C(C)(C)C(C)CC(C)c1cc[n+](C)cc1</smiles>

Figure 4. Structures of polymers that were used for the generation of polymersomes with photosynthetic activity. Abbreviations are listed in the footnote of Table 1. The polybutadiene (PBD)-containing triblock copolymers were prepared from hydroxyl terminated polybutadiene that has been mainly formed by 1,4-addition [55].

\section{3. (Artificial) Photosynthetic Systems for Light-Driven Proton Translocation}

If light is supposed to be utilized for energy consuming cascade reactions, in the perspective of sustainable green production processes, the conversion of light energy into a molecular energy currency (until now, mostly ATP, NADH, and NADPH being generated in vitro) has to be the basis of all considerations. We therefore compiled an overview of available (artificial) photosynthetic systems, which have been proved to be functional after insertion into the membrane of artificial vesicular compartments.

Until now, there are three types of photosynthetic systems which have been employed successfully in artificial vesicles. The first type comprises the light-activated proton gates bacteriorhodopsin (BR) and proteorhodopsin (PR). BR, as the first identified microbial rhodopsin, was discovered in the haloarchaeon Halobacterium salinarum [79]. It appears purple due to the absorption of light at $560 \mathrm{~nm}$ and utilizes light energy to pump protons from the cytoplasm into the extracellular space [80]. BR has been successfully expressed in eukaryotic cells (e.g., yeast [81-83] and oocytes [84]) and bacteria [85]. However, in E. coli it was poorly folded into the correct conformation needed to bind the chromophore. PR also generates proton gradients across membranes via utilization of light energy in bacteria, with absorption maxima in the blue-green visible light [86]. PR can be expressed in E. coli in its fully functional form, with two additional genes being necessary for the synthesis of the involved chromophore [86-88]. The generated proton gradients by both proton pumps mentioned could be employed for ATP synthesis as well as for regeneration of the cofactor $\mathrm{NAD}^{+}$to NADH (Figure 5a [89]). 
The second type of photosystems being used for light-driven biocatalysis are the light capturing photosystems of chloroplasts from plants, algae and cyanobacteria as well as their equivalent in photosynthetic bacteria (the reaction center, RC). In plants, algae and cyanobacteria, two photosystems are employed. Photosystem II (PSII) splits water into protons, electrons and oxygen and drives the photophosphorylation via light absorption (absorption maximum at $680 \mathrm{~nm}$ [90]). The proton translocation is coupled with the electron transport chain, leading to the generation of a proton gradient [91]. Via light absorption, electrons are transferred from water to ferredoxin in the oxygenic photosynthesis. This can further regenerate the cofactor $\mathrm{NADP}^{+}$to NADPH to provide the reactions of the Calvin cycle with low-potential electrons, leading to the fixation of $\mathrm{CO}_{2}$ into organic molecules (Figure $5 \mathrm{~b}$ [89]). The photosynthetic RC of purple non-sulfur bacteria, as a transmembrane protein-pigment complex, localizes in the intracytoplasmic membrane and functions as a light-driven ferrocytochrome c-ubiquinone oxidoreductase [92]. Via photo-absorption, charge separation takes place in the special pair of bacteriochlorophyll a in the $\mathrm{RC}$, and electrons are transferred in a cyclic chain with ubiquinone as redox mediator, shuttling protons across the membrane. Two net protons are pumped from the cytoplasm into the periplasm, creating a proton gradient across the photosynthetic membrane to synthesize ATP (Figure 6) [93-95].

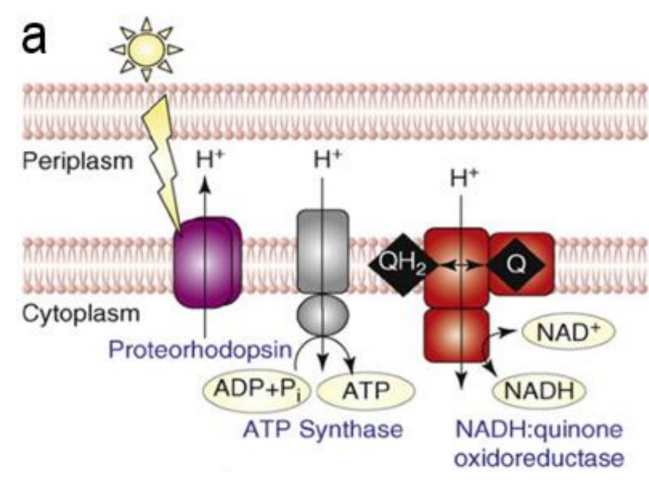

(a)

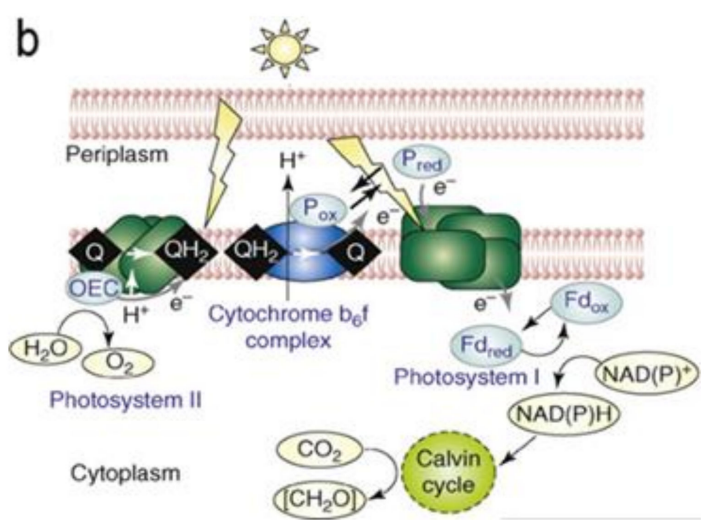

(b)

Figure 5. Light-driven biocatalytic processes in vivo. (a) ATP synthase and NADH:quinone oxidoreductase catalyze the formation of ATP and NADH using the energy stored in proton gradients generated by proteorhodopsin in bacteria. The reversibility of the NADH:quinone oxidoreductase reaction helps to balance the levels of the reduced and oxidized nicotinamide cofactors and of the redox carriers ubiquinone $(\mathrm{Q})$ and ubiquinol $\left(\mathrm{QH}_{2}\right)$. (b) For oxygenic photosynthesis in cyanobacteria, two photosystems are employed, which transfer electrons $\left(\mathrm{e}^{-}\right)$from water to ferredoxin $(\mathrm{Fd})$. Upon excitation of photosystem II, ubiquinone $(\mathrm{Q})$ is reduced to ubiquinol $\left(\mathrm{QH}_{2}\right)$. Subsequently, the cytochrome $\mathrm{b}_{6} \mathrm{f}$ complex re-oxidizes $\mathrm{QH}_{2}$ and reduces plastocyanin $(\mathrm{P})$, which in turn transfers the electrons to the photosystem I. The electron transfer to oxidized ferredoxin $\left(\mathrm{Fd}_{\mathrm{ox}}\right)$ is then triggered by excitation of photosystem I. The reduction of the nicotinamide cofactors links this process to the carbon fixation in the Calvin cycle. Finally, the oxygen-evolving complex (OEC) oxidizes water to regenerate the system for the next electron transfer. For purposes of clarity, the ATP synthase, which also catalyzes the formation of ATP in this system, has been omitted. Reprinted from E. T. Johnson and C. Schmidt-Dannert, Light-energy conversion in engineered microorganisms, Trends in Biotechnology, 26(12), 682-689, Copyright (2008), with permission from Elsevier [89]. 


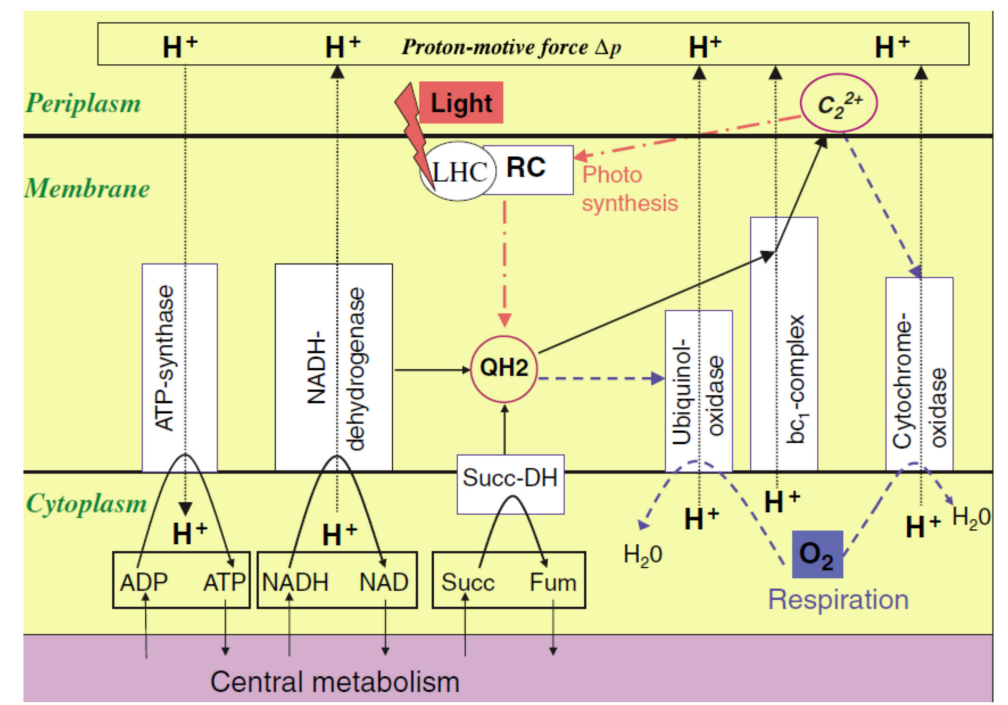

Figure 6. The photophosphorylation and oxidative phosphorylation pathways of purple non-sulfur bacteria. The nicotinamide adenine dinucleotide (NADH) dehydrogenase catalyzes a reduction of the redox carrier ubiquinone $(\mathrm{Q})$ to ubiquinol $\left(\mathrm{QH}_{2}\right)$. This process is coupled to the translocation of protons from the cytoplasm to the periplasm. The succinate dehydrogenase (Succ-DH) oxidizes succinate to fumarate and transfers the two electrons to $\mathrm{Q}$. The heme-containing ubiquinol oxidase, which is also acting as a proton pump, transfers electrons from $\mathrm{QH}_{2}$ to oxygen. The cytochrome $\mathrm{bc}_{1}$ complex mediates the transfer of electrons from the ubiquinol pool to the second type of diffusible redox carrier in the membrane, the cytochrome $c_{2}$, and pumps protons into the periplasm. The cytochrome c oxidase oxidizes two molecules of cytochrome $c_{2}$ and reduces oxygen to water, thereby translocating protons into the periplasm. The photosynthetic apparatus comprises a reaction center (RC) and a light-harvesting complex (LHC) and is involved in the transfer of electrons from cytochrome $c_{2}$ to $\mathrm{QH}_{2}$. This light-driven transfer is special because it proceeds from high to low redox potential. Finally, the adenosine triphosphate (ATP) synthase converts the energy stored in the electrochemical gradient into chemical energy in the form of ATP. Electron flows that are solely photosynthetic or respiratory are indicated by red dashed-dotted and blue dashed lines, respectively. There is no information about stoichiometry in this figure. Reprinted with permission from S. Klamt, H. Grammel, R. Straube, R. Ghosh and E. D. Grilles, Mol Syst Biol., 4:156, Copyright (2008). (doi:10.1038/msb4100191) [95].

Apart from the above mentioned biological photosynthetic systems, the third type is the artificial RC, composed of an electron donor and an acceptor linked to a photosensitive porphyrin, thereby forming a molecular "triad" (carotene-porphyrin-naphthoquinone, (Figure 7) [15,96]. This synthetic RC was coupled with the redox mediator quinone, mimicking the proton-translocating function of natural proteins and creating proton gradients across liposomal membranes upon photoexcitation [96]. Steinberg and coworkers have reported that 1000 molecules of the molecular triad as well as 500 molecules of quinone were integrated into the lipid bilayer (liposomes with a diameter of $150 \mathrm{~nm}$, composed of phosphatidylcholine and phosphatidic acid, 10:1 weight ratio plus $20 \%$ cholesterol) [15]. Compared with all above-mentioned natural biological photosynthetic systems, the artificial $\mathrm{RC}$ has the highest integration capacity per liposome, yielding $7 \pm 1 \mathrm{ATP}$ per $\mathrm{CF}_{0} \mathrm{~F}_{1}$ per second. The second-best result was obtained with a system employing around 470 photosystems (PR+PSII) per liposome (with a diameter of $100 \mathrm{~nm}$ ), yielding $4.3 \pm 0.1$ ATP per ATP synthase per second [20]. However, to increase the final number of generated ATP molecules per artificial compartment it is necessary to further increase the amount of ATP synthase molecules integrated per artificial vesicle as well as to maintain their high bioactivity during the assembly of the system and during the course of the reaction. 


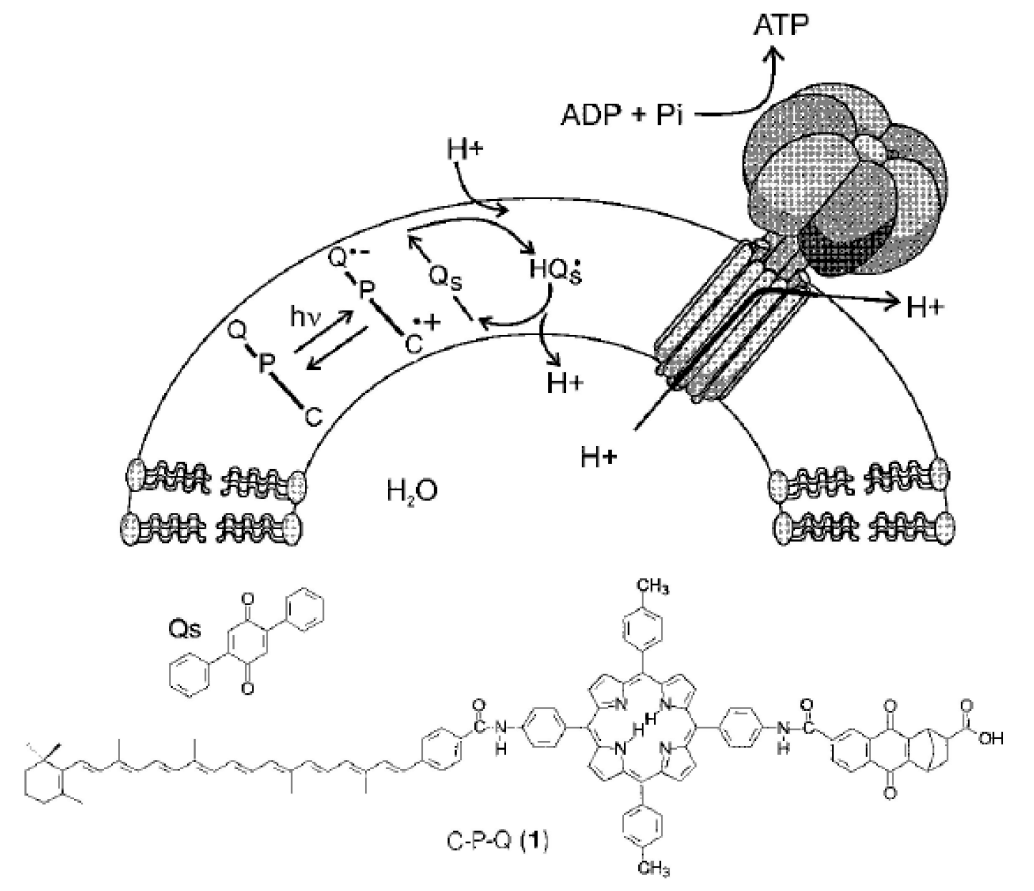

Figure 7. The chloroplastic $\mathrm{F}_{0} \mathrm{~F}_{1}$-ATP synthase and an artificial photosynthetic apparatus based on a molecular triad were reconstituted into liposomes. The molecular triad consisted of carotene-porphyrin-naphthoquinone (C-P-Q). The photocycle that translocates protons into the lumen of the liposome is shown. The triad generates the species $\mathrm{C}^{\bullet+}-\mathrm{P}-\mathrm{Q}^{\bullet-}$ upon light excitation. The intramolecular redox potential of this molecule, bearing a carotenoid radical cation and a naphthoquinone radical anion, is connected to a proton transfer mediated by a quinone $\left(\mathrm{Q}_{\mathrm{S}}\right)$, which is alternating between a reduced and an oxidized state. The reduction takes place at the vesicle surface when $\mathrm{Q}_{\mathrm{S}}$ accepts an electron from the radical anion and gets protonated to the semiquinone $\mathrm{HQ}_{S}{ }^{\bullet}$. This species shuttles both, the proton and the electron, to the inner membrane surface where the oxidation by the $\mathrm{C}^{\bullet+}$-P-Q species takes place. The proton is set free into the vesicle lumen and the resulting proton motive force leads to the generation of ATP by the action of the embedded $\mathrm{F}_{0} \mathrm{~F}_{1}$-ATP synthase. Reprinted by permission from Nature, Light-driven production of ATP catalysed by F0F1-ATP synthase in an artificial photosynthetic membrane, G. Steinberg-Yfrach, J.-L. Rigaud, E. N. Durantini, A. L. Moore, D. Gust and T. A. Moore, Copyright (02041998) (doi:10.1038/33116) [15].

\section{Insertion Orientation and Efficiency}

For an efficient conversion of light energy into the form of energy-rich molecules such as ATP, the involved membrane proteins have to insert in correct orientation into the membrane. It is not trivial to control the orientation of the membrane proteins in the course of the insertion and to increase their (directed) integration efficiency into the membranes of artificial vesicles, since the reconstitution of most membrane proteins in vitro occurs in random orientation [17,97-103].

There have been quite a few strategies tested until now for controlling the orientation of membrane proteins during insertion into liposomes and polymersomes. A protein that has been in employed in many studies is the RC from Rhodobacter sphaeroides. This RC has an overall asymmetric hydrophobicity, with two hydrophobic subunits called L and $\mathrm{M}$ and a hydrophilic $\mathrm{H}$ subunit [104]. For this protein, it has been shown that there is a positive correlation between the vesicle size of liposomes and the net-orientation of the RC [105]. The percentage of RCs in their physiological orientation decreased from $82 \%$ in the largest vesicle population with diameters $>200 \mathrm{~nm}$ to $64 \%$ in the smallest vesicle population with diameters around $80 \mathrm{~nm}$. Importantly, both values were determined at the same lipid-to-protein ratio of 560. In the same study, the effect of the ionic strength was investigated and a strongly negative correlation was found leading to an almost unidirectional insertion at very low ionic strength. Another study showed that the charge status of the lipids also affected the 
RC orientation since $70 \%$ of RCs exposed their H-subunit outside of positively charged liposomes while their orientation was inversed $(60-70 \%)$ in neutral and negatively charged liposomes [106]. The asymmetric hydrophobicity of the RC from $R$. sphaeroides has also been utilized for oriented insertion. Mavelli and coworkers (2017) reconstituted this protein into giant lipid vesicles $(20 \mu \mathrm{m})$ using a droplet emulsion transfer method (Figure 8). The RC was stabilized in an aqueous solution by detergents, leading to RC-containing micelles. This micellar solution was then emulsified in a lipid-rich oil phase to form water-in-oil (w/o) droplets. The H subunit of the RC (indicated by the orange color), due to its hydrophilic property, preferred to face toward the aqueous core of the droplet and inserted in its physiological orientation. This method yielded up to $90 \pm 1 \%$ physiologically oriented RCs in the liposomal membranes, which generated a pH-gradient after light induction [73]. The same water-in-oil method was used by Yanagisawa et al. (2011) to facilitate an oriented insertion of the membrane protein KcsA into giant unilamellar vesicles [107].
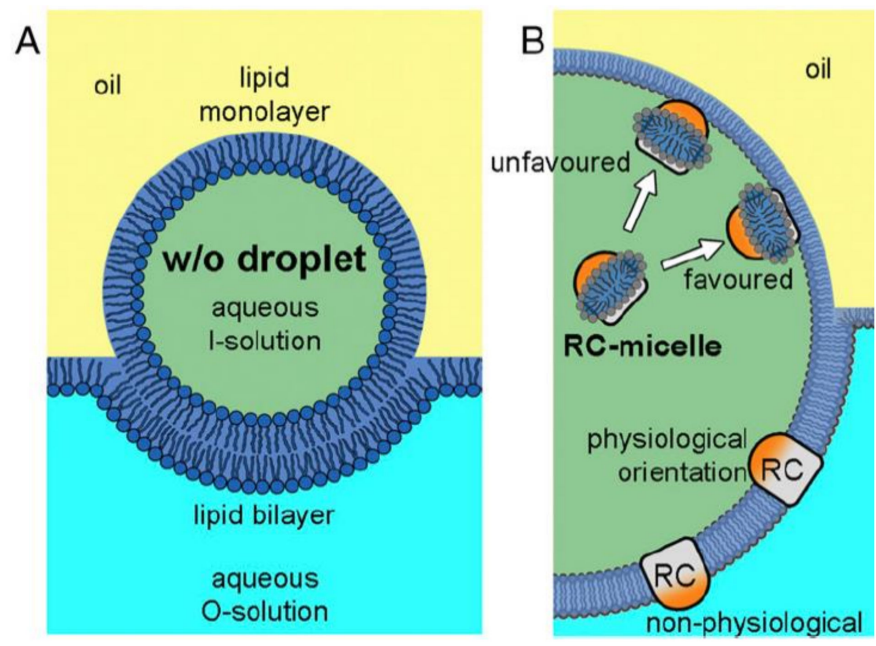

Figure 8. Droplet transfer method for the directed reconstitution of reaction centers (RC) into giant lipid vesicles. (A) Water-in-oil (w/o) droplets, which were formed by emulsifying an aqueous solution (I-solution) in an oil phase, were transferred into an aqueous phase (O-solution) by centrifugal forces. (B) For the reconstitution of reaction centers (RCs), w/o droplets were formed in the presence of RC-containing micelles. Using this method, a high percentage of correctly oriented RCs in giant lipid vesicles was achieved since the hydrophilic $\mathrm{H}$ subunit of the RC (depicted in orange) preferred to face toward to the aqueous core of the droplet. Reprinted with permission from E. Altamura, F. Milano, R. R. Tangorra, M. Trotta, O. H. Omar, P. Stano and F. Mavelli, Highly oriented photosynthetic reaction centers generate a proton gradient in synthetic protocells, PNAS, 2017, 114(15), 3837-3842 [73].

As mentioned in Section 2.3, the asymmetry of the natural membrane is of significant importance for the directed insertion of membrane proteins in vivo. Tunuguntla et al. [74] have demonstrated that the orientation of PR in liposomal membranes could be controlled by the lipid compositions. PR is asymmetrically charged, with an abundance of positively charged residues at the C-terminus and a number of negatively charged residues at the N-terminus [108]. Lipids with positively charged, negatively charged and zwitterionic headgroups were tested and it turned out that the terminus, which was charged in the same way as the lipid, was positioned on the surface of the outer bilayer (Figure 9). 
A Headgroups of charged or zwitterionic lipids used to form proteoliposomes

\begin{tabular}{|c|c|c|c|c|}
\hline Lipid (charge) & DOPC & DOTAP (+) & POPC & POPG (-) \\
\hline
\end{tabular}
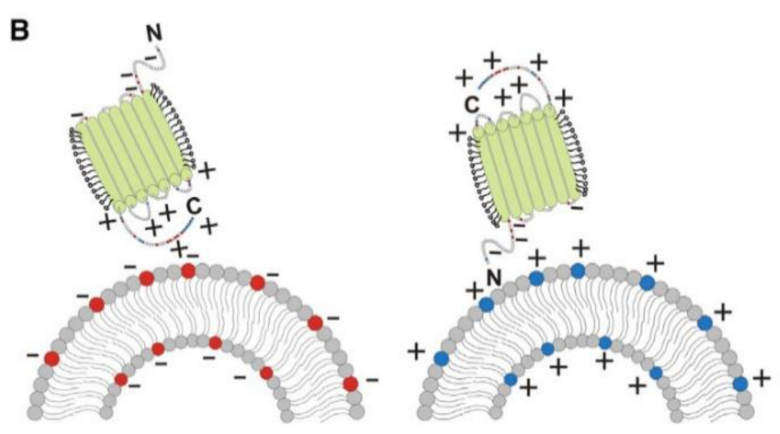

Figure 9. Directionality of the insertion of proteorhodopsin (PR) into liposomes. (A) Different lipids, which have positively charged, negatively charged or zwitterionic headgroups, were tested. (B) The asymmetric charge distribution at the $\mathrm{C}$-/ $\mathrm{N}$-termini of proteorhodopsin control the orientation of the protein during insertion. The terminus of PR, which has the same charge as the liposome bilayer, localizes on the surface of the outer bilayer. Reprinted from R. Tunuguntla, M. Bangar, K. Kim, P. Stroeve, C. M. Ajo-Franklin, Lipid bilayer composition can influence the orientation of proteorhodopsin in artificial membranes, Biophys. J, 105(6), 1388-1396, Copyright (2013) with permission from Elsevier [74].

In case of polymersomes it has been shown that the chemical composition of the amphiphilic polymers forming the vesicles is able to affect the orientation of the membrane proteins in the polymeric membrane as well [109-112]. The RC from R. sphaeroides was spontaneously reconstituted by Liang and coworkers into hierarchically organized membrane arrays of synthetic block copolymers via a charge-interaction-directed mechanism and stayed fully active as indicated by spectroscopic examination [72]. Moreover, a directed insertion of membrane proteins can be induced by using asymmetric membranes composed of amphiphilic $\mathrm{ABC}$ triblock copolymers with two chemically different water-soluble blocks A and C [113].

Protein engineering has also been applied to tackle the problem of membrane protein integration in random orientation. A sophisticated method to avoid the undesired proton pumping activity of wrongly oriented proton pumps is the selective deactivation of proteins that were integrated in non-physiological orientation. D. Fotiadis and coworkers developed a rationally designed PR mutant with an engineered on/off switch based on the reversible chemical modification of an introduced cysteine residue that allows for the selective deactivation of wrongly oriented PR molecules [75]. A clear disadvantage of this method is the net-loss of proton pumping activity which is undesirable in view of the laborious isolation and reconstitution of proton pumps. This drawback can be circumvented by using a different protein engineering strategy that directly affects the orientation of the PR molecules during their insertion. This strategy was inspired by the observation that some proteins always insert almost exclusively in one orientation into preformed vesicles. This phenomenon occurs if a membrane protein has a hydrophilic domain that impedes its translocation to the other side of the membrane [114]. A well-known example is the ATP synthase with its characteristic catalytic head-group [70]. Recently, using the example of PR it was shown that this effect is also achieved if membrane proteins are artificially fused to a soluble protein, such as green or red fluorescent protein (Figure 10) [76,78]. This method represents an elegant and highly effective way to control the orientation of the membrane proteins. A similar effect was achieved by His-tag mediated attachment of large Ni-NTA coated silicate particles to the C-terminus of PR to enhance the insertion via the $\mathrm{N}$-terminus into preformed membranes of proteoliposomes [115]. 

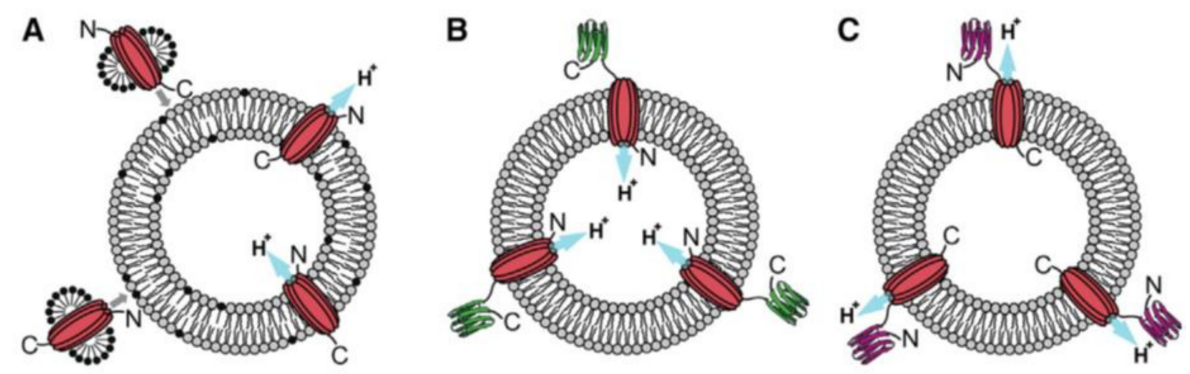

Figure 10. Control of the orientation of proteorhodopsin (PR) in liposomal membranes by artificial fusion to soluble proteins. (A) Unmodified PR was reconstituted into liposomes in random orientation. (B) With a C-terminally fused hydrophilic domain (in this case: green fluorescent protein), PR inserted into liposomes with the $\mathrm{N}$-terminus pointing into the vesicle lumen. (C) If the N-terminus was fused to a water-soluble red fluorescent protein (mCherry) domain, PR inserted into the liposome in the opposite orientation and the C-terminus was pointing into the vesicle lumen. Reprinted from N. Ritzmann, J. Thoma, S. Hirschi, D. Kalbermatter, D. Fotiadis, Fusion domains guide the oriented insertion of light-driven proton pumps into liposomes, Biophys. J, 113, 1181-1186, Copyright (2017) with permission from Elsevier [76].

\section{Light-Driven Biocatalysis in Artificial Compartments}

As the most important energy currency in living organisms, ATP powers most of the energy consuming reactions and provides tight regulation of many biosynthetic pathways. For biotechnological applications the provision of ATP, therefore, is of prime importance. ATP is generated by $\mathrm{F}_{0} \mathrm{~F}_{1}$-ATP synthases in living organisms in two ways: (1) oxidative phosphorylation and (2) photophosphorylation via light-induced proton gradients [116-118]. ATP synthases have been reported to be functionally reconstituted within artificial vesicles, e.g., liposomes [13-15,19,20,77,119], polymersomes [54,70,71], as well as within protein- or polymer-based microcapsules [120-122]. ATP synthesis was powered by the proton gradients generated by coupling with BR [12,14,54,70,71,77,119], PSII/PR [20], PSII [19], and artificial RC [15].

To efficiently produce ATP from light-driven artificial compartments, it is very important to maintain the bioactivity of the photosystems as high as possible. That is especially crucial for the membrane associated protein PSII, which is a large protein multiunit complex with a molecular mass up to $350 \mathrm{kDa}$ [123]. It has been shown to be difficult to preserve a high bioactivity of PSII after being reconstituted into nonbiological membrane systems [124]. The group of Li has reported that, by using a simple coprecipitation method [125], PSII was entrapped in a hydrogel-like porous microsphere, followed by coating with ATPase proteoliposomes on its surface (Figure 11) [19]. This microsphere was proved by a photoreduction assay to be helpful to preserve the bioactivity of PSII. 


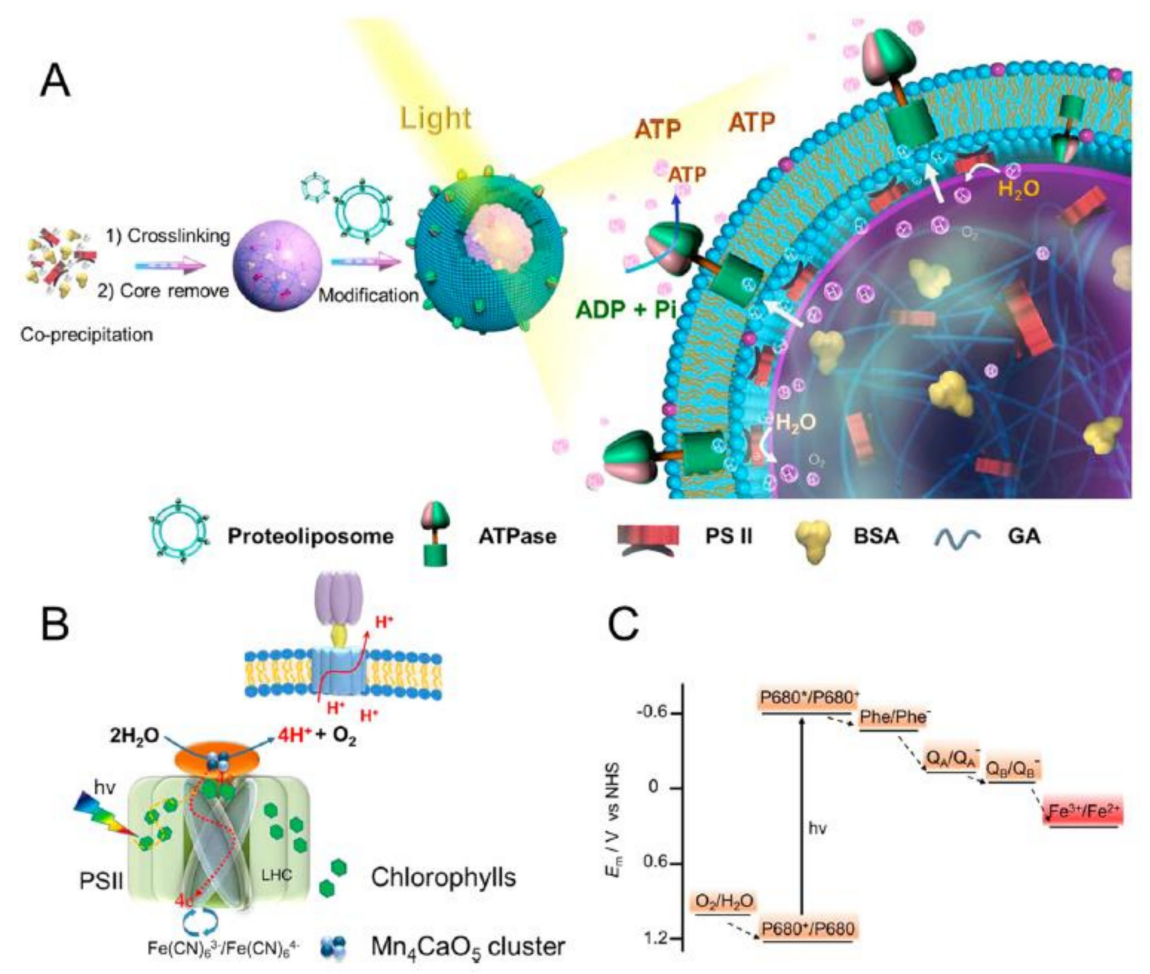

Figure 11. (A) Light-driven biocatalysis in an artificial chloroplast, consisting of a PSII-based microsphere and a $\mathrm{F}_{0} \mathrm{~F}_{1}$-ATPase proteoliposome coating. For this assembly, hydrogel-like PSII-based microspheres were prepared through co-precipitation of bovine serum albumin, PSII, and calcium carbonate. After crosslinking by glutaraldehyde, the calcium carbonate core was removed. Subsequently, $\mathrm{F}_{0} \mathrm{~F}_{1}$-ATPase proteoliposomes were coated on the surface of these microspheres. Under illumination, the entrapped PSII split water into protons, which led to the generation of ATP by the $\mathrm{F}_{0} \mathrm{~F}_{1}$-ATPase proteoliposomes on the shell. (B) The photonic energy captured by the light-harvesting complex (LHC) of PSII evokes several charge separation and electron-transfer processes. The release of protons occurs at the site of $\mathrm{Mn}_{4} \mathrm{CaO}_{5}$ cluster. The generated proton gradient prompts the rotational catalysis of $\mathrm{F}_{0} \mathrm{~F}_{1}$-ATPase in the coating. (C) Redox potential scheme during the electron transfer. Reprinted with permission from X. Feng, Y. Jia, P. Cai, J. Fei and J. Li, Coassembly of photosystem II and ATPase as artificial chloroplast for light-driven ATP synthesis, ACS Nano, 2016, 10(1), 556-561, Copyright (2016) American Chemical Society [19].

Applications of the above-mentioned light-driven artificial compartments are not constricted to mere ATP synthesis, which can be further utilized to supply energy for ATP-consuming (cascade) reactions. Shin and coworkers demonstrated an artificial photosynthetic organelle which was constructed by co-reconstituting plant-derived PSII and PR into the same liposomal compartment (Figure 12a), and the two photoconverters exhibited independent optical activation (Figure 12b) [20]. ATP was synthesized via red light illumination whereas its synthesis was hindered upon green light exposure. These photosynthetic organelles were further encapsulated within giant vesicles $(15 \mu \mathrm{m})$, together with all components needed for an ATP-dependent actin polymerization. Upon light induction, protons translocated across the lipid membrane from the giant vesicle lumen into liposomal lumen and ATP was generated in the lumen of giant vesicles to further energize the actin polymerization (Figure 12c). Additionally, the ATP-producing photosynthetic organelles were suspended in an aqueous solution to couple them with carbon fixation. For this purpose, pyruvate carboxylase, acetyl-coenzyme A and bicarbonate were added to the reaction buffer. Direct coupling between carbon fixation and ATP synthesis was indicated by the formation of oxaloacetate as well as its abolishment due to the addition of an inhibitor of the pyruvate carboxylase. The coupling between ATP-consuming metabolic reactions 
and controllable light-driven ATP synthesis represents an important step toward the establishment of light-driven biocatalytic systems for the preparative synthesis of chemicals.

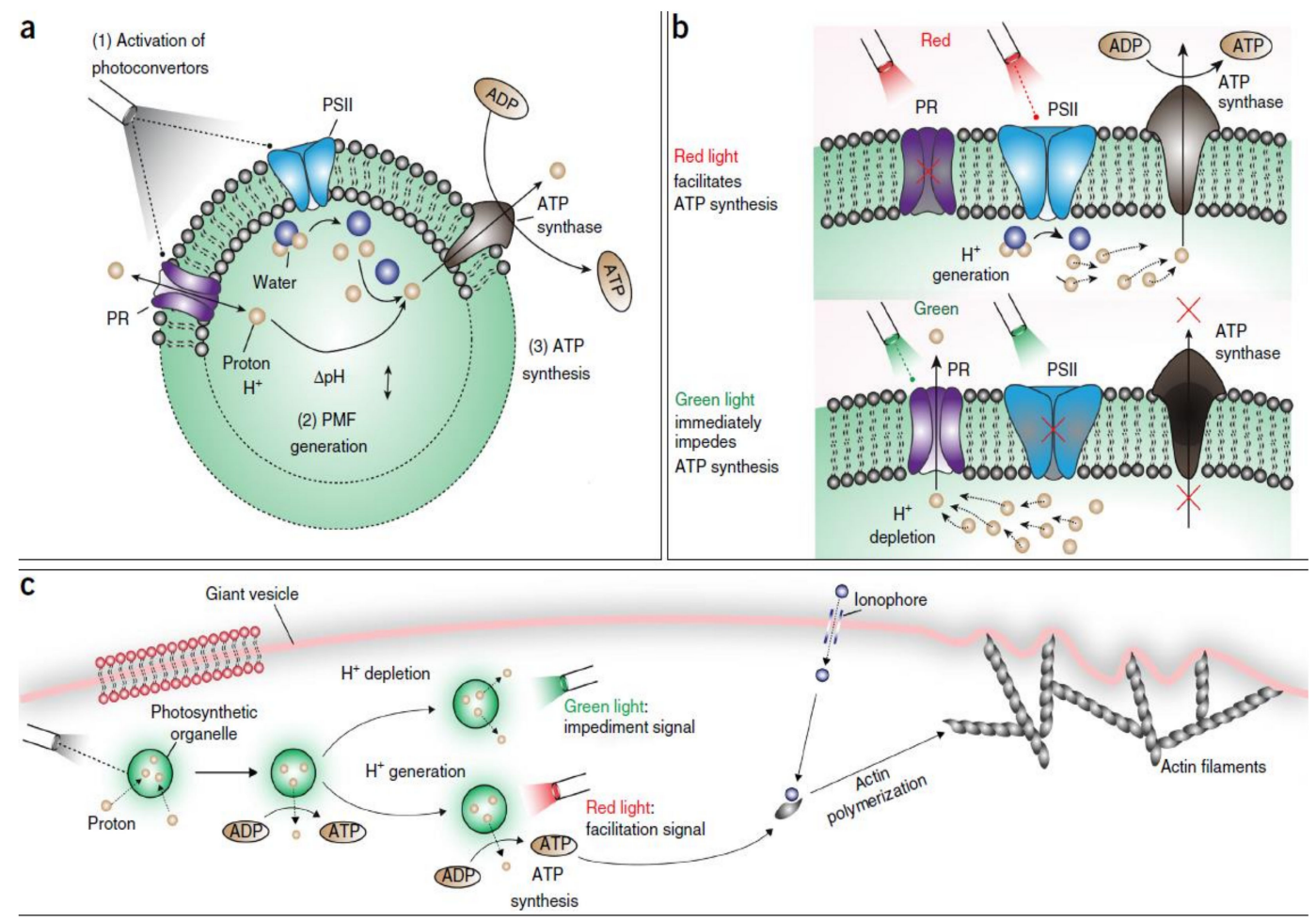

Figure 12. Artificial photosynthetic organelles and their application. (a) Via light activation, photosynthetic system II (PSII) and proteorhodopsin (PR) created a proton gradient and ATP was produced. (b) With the same photosynthetic organelle, ATP synthesis was controlled by an optical switch. Red light facilitated ATP synthesis whereas green light hindered its production. (c) Encapsulation of the photosynthetic organelle as energy module within a giant vesicle for the coupling of ATP synthesis with actin polymerization. Red light facilitated the actin filament growth and green light impeded its growth. Reprinted by permission from Springer Nature, K. Y. Lee, S.-J. Park, K. A. Lee, S.-H. Kim, H. Kim, Y. Meroz, L. Mahadevan, K.-H. Jung, T. K. Ahn, K. K. Parker and K. Shin, Photosynthetic artificial organelles sustain and control ATP-dependent reactions in a protocellular system, Nat Biotechnol, Copyright (2018) [20].

Apart from liposomes and polymersomes, larger artificial compartments have been created by using surfactant proteins or detergents. Montemagno and coworkers have integrated $B R / F_{0} F_{1}$ ATPase into liposomes and polymersomes. They used the Tungara frog surfactant protein Ranaspumin-2 and the surfactant Tween-20 to form so called "foam channels", which functioned as the larger compartments and hosted light-driven ATP generating liposomes and polymersomes, respectively, together with multi-enzyme-systems of the Calvin-Benson-Bassham (CBB) cycle with glyceraldehyde-3-phosphate (G3P) as the product. To further assimilate G3P to glucose, corresponding enzymes were added. This co-entrapment in the solution within the foam channels made it possible to efficiently couple the ATP consuming metabolic cascade reactions with the light-induced ATP synthesis (Figure 13) [71]. 


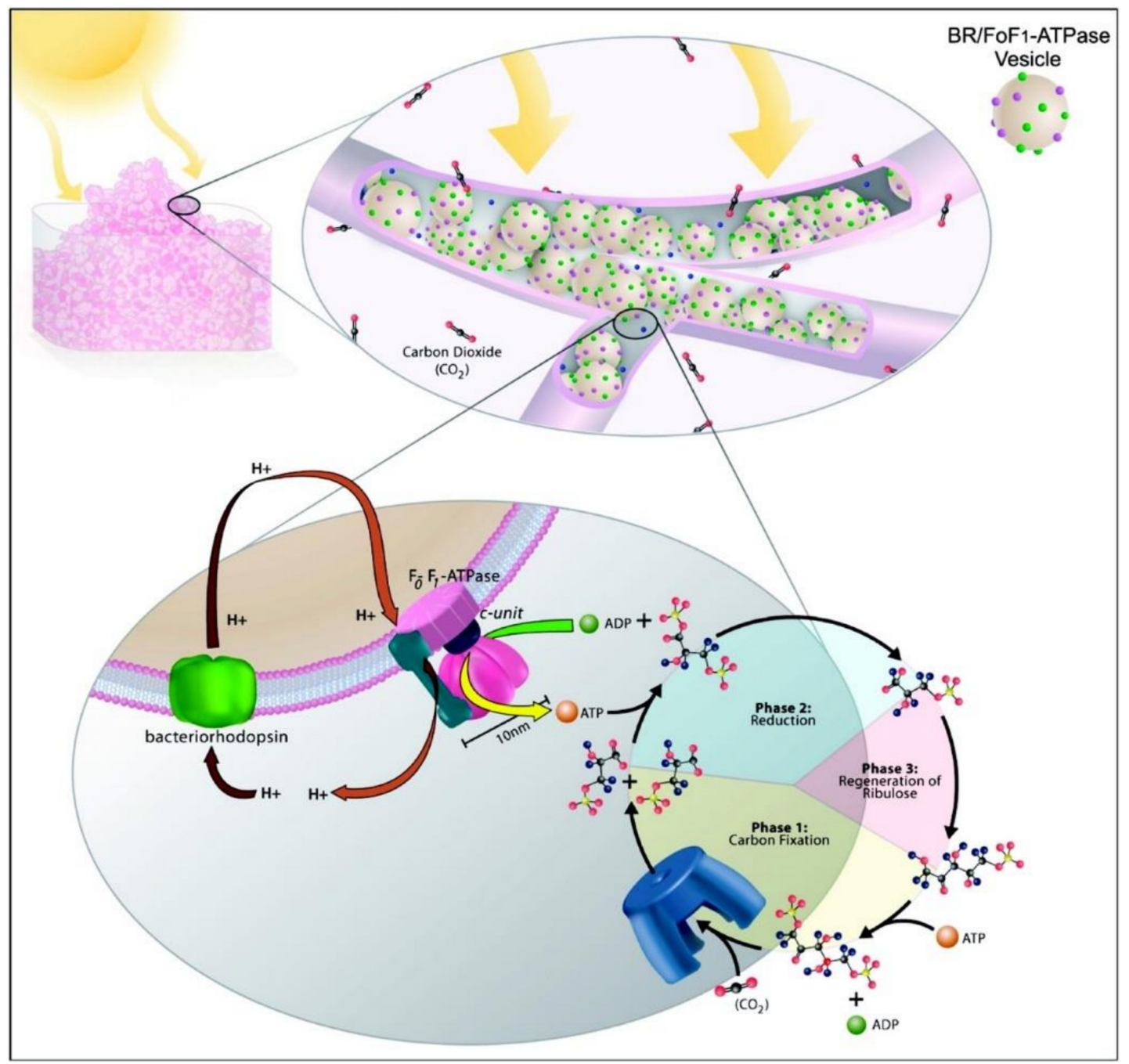

Figure 13. A foam-based artificial photosynthetic system. $B R / F_{0} F_{1}$ ATP synthase was reconstituted in polymersomes or liposomes. These ATP-producing vesicles were hosted within the foam channels and coupled with multi-enzyme systems to power carbon fixation. For this purpose, the enzymes of the Calvin-Benson-Bassham (CBB) cycle were employed. The reaction is divided into three phases. Phase 1: The enzyme RuBisCo (ribulose 1,5-bisphosphate carboxylase) catalyzes the carboxylation of ribulose-1,5-bisphosphate to form an unstable C6-compound that decomposes into two molecules of 3-phosphoglycerate. In phase 2, 3-phosphoglycerate is phosphorylated and reduced to glyceraldehyde 3-phosphate under consumption of ATP and NADH (the cofactor is not shown in the figure). In phase 3, glyceraldehyde 3-phosphate molecules are used for the formation of the C6-sugar and the regeneration of ribulose-1,5-bisphosphate. Reprinted with permission from D. Wendell, J. Todd and C. Montemagno, Artificial photosynthesis in Ranaspumin-2 based foam, Nano Lett., 2010, 10(9), 3231-3236, Copyright (2010) American Chemical Society [71].

\section{Why Is Light-Driven Biocatalysis Interesting?}

The current examples of vesicle-based light-driven biocatalysis are only of academic interest. However, these studies have to be regarded as pioneering examples for artificial reaction systems that make use of light energy for the generation of organic compounds. Due to the complexity of the systems, it is obvious that their preparative application should first focus on high-value products. Biotransformations employing purified enzymes that catalyze ATP- or $\mathrm{NAD}(\mathrm{P}) \mathrm{H}$-consuming reactions, which are not compatible with current cofactor regeneration systems, e.g., due to inhibition phenomena or complicated product separation, would represent good starting points. Recent advances in the 
fields of large-scale production of polymersomes and the development of biocatalytically active nanoreactors, which could be combined with the photosynthetic vesicles in a modular fashion, are of prime importance for the realization of such syntheses (see review [126]). In the long run, one might even think about the production of low-cost compounds such as biofuels, if advances in the state of the art in the areas of membrane protein production and assembly of the photosynthetically active vesicles improve the cost-efficiency of the syntheses. A major challenge in this context is the low efficiency of natural photosynthesis. Plants employing the Calvin-Benson-Bassham (CBB) cycle, so-called C3 plants, have an observed photosynthetic efficiency of around 1\% with an estimated upper limit of $4.5 \%$ [127]. For comparison, the highest reported efficiency of the conversion of solar energy into electricity by solar cells, which are employed in photovoltaic systems, amounts currently to $46.0 \%$ [128]. In recent years, microalgae have been widely discussed as better alternative for biofuel production compared to land plants since they should have higher efficiencies due to the lack of cells without photosynthetic activity, which are responsible for a loss of $30 \%$ of photons $[127,129]$. This advantage would also be true for artificial photosynthetic vesicles. Another advantage would be the possibility of optimizing the relation of light-harvesting pigments to reaction centers. This would not only reduce the photodamage to the system, but also help to avoid saturation at high light intensities, which is reached in natural systems at an intensity corresponding to $20 \%$ of full sunlight [127].

\section{Conclusion and Outlook}

The utilization of solar energy for the generation of high-energy chemical bonds requires a reaction system that is able to convert photonic into chemical energy rather than dissipating it into heat. Natural phototrophic organisms achieve this goal via the light-induced generation of electrochemical gradients across membranes, whose energy can be conserved in form of energy-rich molecules such as ATP. In recent years, significant advances have been made in the construction of photosynthetically active membrane-enveloped compartments on the basis of liposomes and polymersomes that mimic these natural principles. A broad variety of vesicles with (artificial) photosynthetic systems in their membranes have been generated, predominantly by embedding natural membrane proteins with proton pumping activity into diverse lipid or polymer membranes. Since the unidirectional transport of molecules is a fundamental prerequisite for the efficient formation of electrochemical gradients, much research effort has been devoted to control the orientation of the membrane proteins during the insertion. In this context, the generation of artificial fusion proteins between membrane proteins and soluble fusion partners (such as GFP) has been shown to be an easy but powerful tool to facilitate a directed insertion [78]. First encouraging examples for the synthesis of chemical compounds by light-driven biocatalysis have been published such as the coupling of light-controlled ATP production with energy-dependent carbon fixation reactions resulting in the production of glucose [71] or oxaloacetate [20]. These studies demonstrate the general feasibility of the vesicle-based biocatalytic concept and can be regarded as first steps on the way to sustainable processes employing these exciting new tools. The future goal will be to use artificial photosynthetic mechanisms to power a broad variety of biocatalytic reactions and to employ this technology in the development of a new generation of green production processes of important chemical compounds. In addition to ATP-consuming (cascade) reactions, synthetic routes involving NAD $(\mathrm{P}) \mathrm{H}$-dependent oxidoreductases could greatly benefit from the utilization of light energy for the reduction of $\mathrm{NAD}(\mathrm{P})^{+}$as cost effective and inherently sustainable cofactor regeneration method. In a long-term perspective, even the investigation of biofuel production using these artificial vesicles might be conceivable. However, to accomplish the transition from the proof-of-concept status to chemical reactions on a preparative (or even industrial) scale, there are still major challenges to be addressed. Most importantly, the purification of membrane proteins is extremely cumbersome and has to be significantly optimized to make available the amounts required for large-scale applications. However, the tremendous research efforts that are currently devoted to cell-free protein expression could lead to the development of an important enabling technology for 
light-driven biocatalysis and speed up the establishment of this catalytic concept as a critical tool of future green chemistry.

Author Contributions: G.W. drafted the manuscript. K.C. participated in the design, coordination and helped to draft the manuscript. Both authors read and approved the final manuscript.

Funding: G.W. thanks the BMBF (German Federal Ministry of Education and Research), grant number 031B0221 for financial support.

Acknowledgments: The authors gratefully acknowledge Andreas Perlick for his support, from the braining storming phase to the final version.

Conflicts of Interest: The authors declare no competing financial interest.

\section{References}

1. Schwander, T.; Schada von Borzyskowski, L.; Burgener, S.; Cortina, N.S.; Erb, T.J. A synthetic pathway for the fixation of carbon dioxide in vitro. Science 2016, 354, 900-904. [CrossRef] [PubMed]

2. Rideau, E.; Dimova, R.; Schwille, P.; Wurm, F.R.; Landfester, K. Liposomes and polymersomes: A comparative review towards cell mimicking. Chem. Soc. Rev. 2018, 47, 8572-8610. [CrossRef] [PubMed]

3. Tanner, P.; Baumann, P.; Enea, R.; Onaca, O.; Palivan, C.; Meier, W. Polymeric Vesicles: From Drug Carriers to Nanoreactors and Artificial Organelles. Acc. Chem. Res. 2011, 44, 1039-1049. [CrossRef] [PubMed]

4. Bangham, A.D.; Horne, R.W. Negative staining of phospholipids and their structural modification by surface-active agents as observed in the electron microscope. J. Mol. Biol. 1964, 8, 660-668. [CrossRef]

5. Alavi, M.; Karimi, N.; Safaei, M. Application of Various Types of Liposomes in Drug Delivery Systems. Adv. Pharm. Bull. 2017, 7, 3-9. [CrossRef] [PubMed]

6. Rahimpour, Y.; Hamishehkar, H. Liposomes in cosmeceutics. Expert Opin. Drug Delivery 2012, 9, 443-455. [CrossRef] [PubMed]

7. Emami, S.; Azadmard-Damirchi, S.; Peighambardoust, S.H.; Valizadeh, H.; Hesari, J. Liposomes as carrier vehicles for functional compounds in food sector. J. Exp. Nanosci. 2016, 11, 737-759. [CrossRef]

8. Jesorka, A.; Orwar, O. Liposomes: Technologies and Analytical Applications. Annu. Rev. Anal. Chem. 2008, 1, 801-832. [CrossRef]

9. Lu, K.-Y.; Tao, S.-C.; Yang, T.-C.; Ho, Y.-H.; Lee, C.-H.; Lin, C.-C.; Juan, H.-F.; Huang, H.-C.; Yang, C.-Y.; Chen, M.-S.; et al. Profiling lipid-protein interactions using nonquenched fluorescent liposomal nanovesicles and proteome microarrays. Mol. Cell. Proteomics 2012, 11, 1177-1190. [CrossRef]

10. Zhu, H.; Bilgin, M.; Bangham, R.; Hall, D.; Casamayor, A.; Bertone, P.; Lan, N.; Jansen, R.; Bidlingmaier, S.; Houfek, T.; et al. Global Analysis of Protein Activities Using Proteome Chips. Science 2001, 293, 2101. [CrossRef]

11. Jørgensen, I.L.; Kemmer, G.C.; Pomorski, T.G. Membrane protein reconstitution into giant unilamellar vesicles: A review on current techniques. Eur. Biophys. J. 2017, 46, 103-119. [CrossRef] [PubMed]

12. Racker, E.; Stoeckenius, W. Reconstitution of Purple Membrane Vesicles Catalyzing Light-driven Proton Uptake and Adenosine Triphosphate Formation. J. Biol. Chem. 1974, 249, 662-663. [PubMed]

13. Richard, P.; Rigaud, J.-L.; GrÄBer, P. Reconstitution of $\mathrm{CFOF1}$ into liposomes using a new reconstitution procedure. Eur. J. Biochem. 1990, 193, 921-925. [CrossRef] [PubMed]

14. Pitard, B.; Richard, P.; Duñach, M.; Rigaud, J.-L. ATP Synthesis by the F0F1 ATP Synthase from Thermophilic Bacillus PS3 Reconstituted into Liposomes with Bacteriorhodopsin. Eur. J. Biochem. 1996, 235, 779-788. [CrossRef] [PubMed]

15. Steinberg-Yfrach, G.; Rigaud, J.-L.; Durantini, E.N.; Moore, A.L.; Gust, D.; Moore, T.A. Light-driven production of ATP catalysed by F0F1-ATP synthase in an artificial photosynthetic membrane. Nature 1998, 392, 479. [CrossRef] [PubMed]

16. Girard, P.; Pécréaux, J.; Lenoir, G.; Falson, P.; Rigaud, J.-L.; Bassereau, P. A New Method for the Reconstitution of Membrane Proteins into Giant Unilamellar Vesicles. Biophys. J. 2004, 87, 419-429. [CrossRef]

17. Milano, F.; Trotta, M.; Dorogi, M.; Fischer, B.; Giotta, L.; Agostiano, A.; Maróti, P.; Kálmán, L.; Nagy, L. Light induced transmembrane proton gradient in artificial lipid vesicles reconstituted with photosynthetic reaction centers. J. Bioenerg. Biomembr. 2012, 44, 373-384. [CrossRef] 
18. Dezi, M.; Di Cicco, A.; Bassereau, P.; Lévy, D. Detergent-mediated incorporation of transmembrane proteins in giant unilamellar vesicles with controlled physiological contents. Proc. Natl. Acad. Sci. USA 2013, 110, 7276-7281. [CrossRef]

19. Feng, X.; Jia, Y.; Cai, P.; Fei, J.; Li, J. Coassembly of Photosystem II and ATPase as Artificial Chloroplast for Light-Driven ATP Synthesis. ACS Nano 2016, 10, 556-561. [CrossRef]

20. Lee, K.Y.; Park, S.J.; Lee, K.A.; Kim, S.H.; Kim, H.; Meroz, Y.; Mahadevan, L.; Jung, K.H.; Ahn, T.K.; Parker, K.K.; et al. Photosynthetic artificial organelles sustain and control ATP-dependent reactions in a protocellular system. Nat. Biotechnol. 2018, 36, 530-535. [CrossRef]

21. Peyret, A.; Ibarboure, E.; Le Meins, J.-F.; Lecommandoux, S. Asymmetric Hybrid Polymer-Lipid Giant Vesicles as Cell Membrane Mimics. Adv. Sci. 2017, 5, 1700453. [CrossRef] [PubMed]

22. Devaux, P.F. Static and dynamic lipid asymmetry in cell membranes. Biochemistry 1991, 30, 1163-1173. [CrossRef] [PubMed]

23. S, B.M. Phospholipids: More about Less. Nature 1972, 236, 11. [CrossRef]

24. Heijne, G.; Gavel, Y. Topogenic signals in integral membrane proteins. Eur. J. Biochem. 1988, 174, 671-678. [CrossRef]

25. Lin, Q.; London, E. The Influence of Natural Lipid Asymmetry upon the Conformation of a Membrane-inserted Protein (Perfringolysin O). J. Biol. Chem. 2014, 289, 5467-5478. [CrossRef] [PubMed]

26. LoPresti, C.; Lomas, H.; Massignani, M.; Smart, T.; Battaglia, G. Polymersomes: nature inspired nanometer sized compartments. J. Mater. Chem. 2009, 19, 3576-3590. [CrossRef]

27. Winzen, S.; Bernhardt, M.; Schaeffel, D.; Koch, A.; Kappl, M.; Koynov, K.; Landfester, K.; Kroeger, A. Submicron hybrid vesicles consisting of polymer-lipid and polymer-cholesterol blends. Soft Matter 2013, 9, 5883-5890. [CrossRef]

28. Discher, B.M.; Won, Y.-Y.; Ege, D.S.; Lee, J.C.M.; Bates, F.S.; Discher, D.E.; Hammer, D.A. Polymersomes: Tough Vesicles Made from Diblock Copolymers. Science 1999, 284, 1143. [CrossRef]

29. Palivan, C.G.; Goers, R.; Najer, A.; Zhang, X.Y.; Car, A.; Meier, W. Bioinspired polymer vesicles and membranes for biological and medical applications. Chem. Soc. Rev. 2016, 45, 377-411. [CrossRef]

30. Baumann, P.; Tanner, P.; Onaca, O.; Palivan, C.G. Bio-Decorated Polymer Membranes: A New Approach in Diagnostics and Therapeutics. Polymers 2011,3, 173-192. [CrossRef]

31. Elani, Y.; Law, R.V.; Ces, O. Vesicle-based artificial cells as chemical microreactors with spatially segregated reaction pathways. Nat. Commun. 2014, 5, 5305. [CrossRef] [PubMed]

32. Schoonen, L.; van Hest, J.C.M. Compartmentalization Approaches in Soft Matter Science: From Nanoreactor Development to Organelle Mimics. Adv. Mater. 2016, 28, 1109-1128. [CrossRef] [PubMed]

33. Gaitzsch, J.; Huang, X.; Voit, B. Engineering Functional Polymer Capsules toward Smart Nanoreactors. Chem. Rev. 2016, 116, 1053-1093. [CrossRef] [PubMed]

34. Klermund, L.; Poschenrieder, S.T.; Castiglione, K. Biocatalysis in Polymersomes: Improving Multienzyme Cascades with Incompatible Reaction Steps by Compartmentalization. Acs Catal. 2017, 7, 3900-3904. [CrossRef]

35. Bermudez, H.; Brannan, A.K.; Hammer, D.A.; Bates, F.S.; Discher, D.E. Molecular weight dependence of polymersome membrane structure, elasticity, and stability. Macromolecules 2002, 35, 8203-8208. [CrossRef]

36. Lorenceau, E.; Utada, A.S.; Link, D.R.; Cristobal, G.; Joanicot, M.; Weitz, D.A. Generation of Polymerosomes from Double-Emulsions. Langmuir 2005, 21, 9183-9186. [CrossRef] [PubMed]

37. Discher, D.E.; Eisenberg, A. Polymer vesicles. Science 2002, 297, 967-973. [CrossRef]

38. Le Meins, J.F.; Sandre, O.; Lecommandoux, S. Recent trends in the tuning of polymersomes' membrane properties. Eur. Phys. J. E. Soft Matter 2011, 34. [CrossRef]

39. Andersen, O.S.; Koeppe, R.E. Bilayer Thickness and Membrane Protein Function: An Energetic Perspective. Annu. Rev. Biophys. Biomol. Struct. 2007, 36, 107-130. [CrossRef]

40. Garni, M.; Thamboo, S.; Schoenenberger, C.-A.; Palivan, C.G. Biopores/membrane proteins in synthetic polymer membranes. Biochim. Biophys. Acta Biomembr. 2017, 1859, 619-638. [CrossRef]

41. Itel, F.; Najer, A.; Palivan, C.G.; Meier, W. Dynamics of Membrane Proteins within Synthetic Polymer Membranes with Large Hydrophobic Mismatch. Nano Lett. 2015, 15, 3871-3878. [CrossRef] [PubMed]

42. Schwarzer, T.S.; Klermund, L.; Wang, G.; Castiglione, K. Membrane functionalization of polymersomes: alleviating mass transport limitations by integrating multiple selective membrane transporters for the diffusion of chemically diverse molecules. Nanotechnology 2018, 29, 44LT01. [CrossRef] [PubMed] 
43. Nallani, M.; Benito, S.; Onaca, O.; Graff, A.; Lindemann, M.; Winterhalter, M.; Meier, W.; Schwaneberg, U. A nanocompartment system (synthosome) designed for biotechnological applications. J. Biotechnol. 2006, 123, 50-59. [CrossRef] [PubMed]

44. Siti, W.; de Hoog, H.-P.M.; Fischer, O.; Shan, W.Y.; Tomczak, N.; Nallani, M.; Liedberg, B. An intercompartmental enzymatic cascade reaction in channel-equipped polymersome-in-polymersome architectures. J. Mater. Chem. B 2014, 2, 2733-2737. [CrossRef]

45. Schmitt, C.; Lippert, A.H.; Bonakdar, N.; Sandoghdar, V.; Voll, L.M. Compartmentalization and Transport in Synthetic Vesicles. Front. Bioeng. Biotechnol. 2016, 4, 19. [CrossRef] [PubMed]

46. Nardin, C.; Thoeni, S.; Widmer, J.; Winterhalter, M.; Meier, W. Nanoreactors based on (polymerized) ABA-triblock copolymer vesicles. Chem. Commun. 2000, 1433-1434. [CrossRef]

47. Ranquin, A.; Versees, W.; Meier, W.; Steyaert, J.; Van Gelder, P. Therapeutic nanoreactors: combining chemistry and biology in a novel triblock copolymer drug delivery system. Nano Lett. 2005, 5, 2220-2224. [CrossRef]

48. Kumar, M.; Grzelakowski, M.; Zilles, J.; Clark, M.; Meier, W. Highly permeable polymeric membranes based on the incorporation of the functional water channel protein Aquaporin Z. Proc. Natl. Acad. Sci. USA 2007, 104, 20719-20724. [CrossRef]

49. Graff, A.; Fraysse-Ailhas, C.; Palivan, C.G.; Grzelakowski, M.; Friedrich, T.; Vebert, C.; Gescheidt, G.; Meier, W. Amphiphilic Copolymer Membranes Promote NADH:Ubiquinone Oxidoreductase Activity: Towards an Electron-Transfer Nanodevice. Macromol. Chem. Phys. 2010, 211, 229-238. [CrossRef]

50. Nardin, C.; Widmer, J.; Winterhalter, M.; Meier, W. Amphiphilic block copolymer nanocontainers as bioreactors. Eur. Phys. J. E 2001, 4, 403-410. [CrossRef]

51. Dean, H.; Benjamin, C.; Hyeseung, L.; Carlo, D.M. Protein-driven energy transduction across polymeric biomembranes. Nanotechnology 2004, 15, 1084.

52. Denise, W.; Tae-Joon, J.; Jacob, S. Single molecule measurements of channel proteins incorporated into biomimetic polymer membranes. Nanotechnology 2006, 17, 3710.

53. Lee, H.; Ho, D.; Kuo, K.; Montemagno, C.D. Vectorial insertion of bacteriorhodopsin for directed orientation assays in various polymeric biomembranes. Polymer 2006, 47, 2935-2941. [CrossRef]

54. Choi, H.; Montemagno, C.D. Light-Driven Hybrid Bioreactor Based on Protein-Incorporated Polymer Vesicles. IEEE Trans. Nanotechnol. 2007, 6, 171-176. [CrossRef]

55. Hua, D.; Kuang, L.; Liang, H. Self-Directed Reconstitution of Proteorhodopsin with Amphiphilic Block Copolymers Induces the Formation of Hierarchically Ordered Proteopolymer Membrane Arrays. J. Am. Chem. Soc. 2011, 133, 2354-2357. [CrossRef] [PubMed]

56. Ihle, S.; Onaca, O.; Rigler, P.; Hauer, B.; Rodríguez-Ropero, F.; Fioroni, M.; Schwaneberg, U. Nanocompartments with a $\mathrm{pH}$ release system based on an engineered OmpF channel protein. Soft Matter 2011, 7, 532-539. [CrossRef]

57. Einfalt, T.; Goers, R.; Dinu, I.A.; Najer, A.; Spulber, M.; Onaca-Fischer, O.; Palivan, C.G. Stimuli-Triggered Activity of Nanoreactors by Biomimetic Engineering Polymer Membranes. Nano Lett. 2015, 15, 7596-7603. [CrossRef] [PubMed]

58. Srinivas, G.; Discher, D.E.; Klein, M.L. Key roles for chain flexibility in block copolymer membranes that contain pores or make tubes. Nano Lett. 2005, 5, 2343-2349. [CrossRef] [PubMed]

59. Itel, F.; Chami, M.; Najer, A.; Lorcher, S.; Wu, D.L.; Dinu, I.A.; Meier, W. Molecular Organization and Dynamics in Polymersome Membranes: A Lateral Diffusion Study. Macromolecules 2014, 47, 7588-7596. [CrossRef]

60. Dan, N.; Safran, S.A. Self-Assembly in Mixtures of Diblock Copolymers. Macromolecules 1994, $27,5766-5772$. [CrossRef]

61. Pata, V.; Dan, N. The effect of chain length on protein solubilization in polymer-based vesicles (polymersomes). Biophys. J. 2003, 85, 2111-2118. [CrossRef]

62. Muhammad, N.; Dworeck, T.; Fioroni, M.; Schwaneberg, U. Engineering of the E. coli outer membrane protein FhuA to overcome the hydrophobic mismatch in thick polymeric membranes. J. Nanobiotechnol. 2011, 9, 8. [CrossRef] [PubMed]

63. Vriezema, D.M.; Garcia, P.M.; Sancho Oltra, N.; Hatzakis, N.S.; Kuiper, S.M.; Nolte, R.J.; Rowan, A.E.; van Hest, J.C. Positional assembly of enzymes in polymersome nanoreactors for cascade reactions. Angew. Chem. Int. Ed. 2007, 46, 7378-7382. [CrossRef] [PubMed] 
64. Kuiper, S.M.; Nallani, M.; Vriezema, D.M.; Cornelissen, J.J.; van Hest, J.C.; Nolte, R.J.; Rowan, A.E. Enzymes containing porous polymersomes as nano reaction vessels for cascade reactions. Org. Biomol. Chem. 2008, 6, 4315-4318. [CrossRef] [PubMed]

65. Van Dongen, S.F.; Nallani, M.; Cornelissen, J.J.; Nolte, R.J.; van Hest, J.C. A three-enzyme cascade reaction through positional assembly of enzymes in a polymersome nanoreactor. Chemistry 2009, 15, 1107-1114. [CrossRef] [PubMed]

66. Gräfe, D.; Gaitzsch, J.; Appelhans, D.; Voit, B. Cross-linked polymersomes as nanoreactors for controlled and stabilized single and cascade enzymatic reactions. Nanoscale 2014, 6, 10752-10761. [CrossRef] [PubMed]

67. Peters, R.J.R.W.; Marguet, M.; Marais, S.; Fraaije, M.W.; van Hest, J.C.M.; Lecommandoux, S. Cascade Reactions in Multicompartmentalized Polymersomes. Angew. Chem. Int. Ed. 2014, 53, 146-150. [CrossRef]

68. Messager, L.; Burns, J.R.; Kim, J.; Cecchin, D.; Hindley, J.; Pyne, A.L.; Gaitzsch, J.; Battaglia, G.; Howorka, S. Biomimetic Hybrid Nanocontainers with Selective Permeability. Angew. Chem. Int. Ed. 2016, 55, 11106-11109. [CrossRef]

69. Schmidt, S.; Castiglione, K.; Kourist, R. Overcoming the Incompatibility Challenge in Chemoenzymatic and Multi-Catalytic Cascade Reactions. Chemistry 2018, 24, 1755-1768. [CrossRef]

70. Choi, H.J.; Montemagno, C.D. Artificial organelle: ATP synthesis from cellular mimetic polymersomes. Nano Lett. 2005, 5, 2538-2542. [CrossRef]

71. Wendell, D.; Todd, J.; Montemagno, C. Artificial Photosynthesis in Ranaspumin-2 Based Foam. Nano Lett. 2010, 10, 3231-3236. [CrossRef] [PubMed]

72. Kuang, L.; Olson, T.L.; Lin, S.; Flores, M.; Jiang, Y.; Zheng, W.; Williams, J.C.; Allen, J.P.; Liang, H. Interface for Light-Driven Electron Transfer by Photosynthetic Complexes Across Block Copolymer Membranes. J. Phys. Chem. Lett. 2014, 5, 787-791. [CrossRef] [PubMed]

73. Altamura, E.; Milano, F.; Tangorra, R.R.; Trotta, M.; Omar, O.H.; Stano, P.; Mavelli, F. Highly oriented photosynthetic reaction centers generate a proton gradient in synthetic protocells. Proc. Natl. Acad. Sci. USA 2017, 114, 3837-3842. [CrossRef] [PubMed]

74. Tunuguntla, R.; Bangar, M.; Kim, K.; Stroeve, P.; Ajo-Franklin, C.M.; Noy, A. Lipid Bilayer Composition Can Influence the Orientation of Proteorhodopsin in Artificial Membranes. Biophys. J. 2013, 105, 1388-1396. [CrossRef] [PubMed]

75. Harder, D.; Hirschi, S.; Ucurum, Z.; Goers, R.; Meier, W.; Muller, D.J.; Fotiadis, D. Engineering a Chemical Switch into the Light-driven Proton Pump Proteorhodopsin by Cysteine Mutagenesis and Thiol Modification. Angew. Chem. Int. Ed. 2016, 55, 8846-8849. [CrossRef] [PubMed]

76. Ritzmann, N.; Thoma, J.; Hirschi, S.; Kalbermatter, D.; Fotiadis, D.; Muller, D.J. Fusion Domains Guide the Oriented Insertion of Light-Driven Proton Pumps into Liposomes. Biophys. J. 2017, 113, 1181-1186. [CrossRef] [PubMed]

77. Hazard, A.; Montemagno, C. Improved purification for thermophilic F1F0 ATP synthase using n-dodecyl ß-d-maltoside. Arch. Biochem. Biophys. 2002, 407, 117-124. [CrossRef]

78. Goers, R.; Thoma, J.; Ritzmann, N.; Di Silvestro, A.; Alter, C.; Gunkel-Grabole, G.; Fotiadis, D.; Müller, D.J.; Meier, W. Optimized reconstitution of membrane proteins into synthetic membranes. Commun. Chem. 2018, 1, 35. [CrossRef]

79. Oesterhelt, D.; Stoeckenius, W. Rhodopsin-like Protein from the Purple Membrane of Halobacterium halobium. Nat. New Biol. 1971, 233, 149-152. [CrossRef]

80. Haupts, U.; Tittor, J.; Oesterhelt, D. Closing in on bacteriorhodopsin: Progress in Understanding the Molecule. Ann. Rev. Biophys. Biomol. Struct. 1999, 28, 367-399. [CrossRef]

81. Lang-Hinrichs, C.; Queck, I.; Büldt, G.; Stahl, U.; Hildebrandt, V. The archaebacterial membrane protein bacterio-opsin is expressed and N-terminally processed in the yeast Saccharomyces cerevisiae. Mol. Gen. Genet. 1994, 244, 183-188. [CrossRef] [PubMed]

82. Hoffmann, A.; Hildebrandt, V.; Heberle, J.; Büldt, G. Photoactive mitochondria: in vivo transfer of a light-driven proton pump into the inner mitochondrial membrane of Schizosaccharomyces pombe. Proc. Natl. Acad. Sci. USA 1994, 91, 9367-9371. [CrossRef] [PubMed]

83. Hildebrandt, V.; Fendler, K.; Heberle, J.; Hoffmann, A.; Bamberg, E.; Büldt, G. Bacteriorhodopsin expressed in Schizosaccharomyces pombe pumps protons through the plasma membrane. Proc. Natl. Acad. Sci. USA 1993, 90, 3578-3582. [CrossRef] [PubMed]

84. Nagel, G.; Möckel, B.; Büldt, G.; Bamberg, E. Functional expression of bacteriorhodopsin in oocytes allows direct measurement of voltage dependence of light induced H+ pumping. FEBS Lett. 1995, 377, 263-266. [CrossRef] 
85. Karnik, S.; Doi, T.; Molday, R.; Khorana, H.G. Expression of the archaebacterial bacterio-opsin gene with and without signal sequences in Escherichia coli: the expressed proteins are located in the membrane but bind retinal poorly. Proc. Natl. Acad. Sci. USA 1990, 87, 8955-8959. [CrossRef] [PubMed]

86. Walter, J.M.; Greenfield, D.; Bustamante, C.; Liphardt, J. Light-powering Escherichia coli with proteorhodopsin. Proc. Natl. Acad. Sci. USA 2007, 104, 2408-2412. [CrossRef] [PubMed]

87. Martinez, A.; Bradley, A.S.; Waldbauer, J.R.; Summons, R.E.; DeLong, E.F. Proteorhodopsin photosystem gene expression enables photophosphorylation in a heterologous host. Proc. Natl. Acad. Sci. USA 2007, 104, 5590-5595. [CrossRef]

88. Béjà, O.; Aravind, L.; Koonin, E.V.; Suzuki, M.T.; Hadd, A.; Nguyen, L.P.; Jovanovich, S.B.; Gates, C.M.; Feldman, R.A.; Spudich, J.L.; et al. Bacterial Rhodopsin: Evidence for a New Type of Phototrophy in the Sea. Science 2000, 289, 1902. [CrossRef]

89. Johnson, E.T.; Schmidt-Dannert, C. Light-energy conversion in engineered microorganisms. Trends Biotechnol. 2008, 26, 682-689. [CrossRef]

90. Caffarri, S.; Tibiletti, T.; Jennings, R.C.; Santabarbara, S. A comparison between plant photosystem I and photosystem II architecture and functioning. Curr. Protein Pept. Sci. 2014, 15, 296-331. [CrossRef]

91. Nelson, N.; Yocum, C.F. Structure and function of photosystems I and II. Ann. Rev. Plant Biol. 2006, 57, 521-565. [CrossRef] [PubMed]

92. Feher, G.; Allen, J.P.; Okamura, M.Y.; Rees, D.C. Structure and function of bacterial photosynthetic reaction centres. Nature 1989, 339, 111. [CrossRef]

93. Ferguson, S.J.; Jackson, J.B.; McEwan, A.G. Anaerobic respiration in the Rhodospirillaceae: Characterisation of pathways and evaluation of roles in redox balancing during photosynthesis. FEMS Microbiol. Lett. 1987, 46, 117-143. [CrossRef]

94. Stowell, M.H.B.; McPhillips, T.M.; Rees, D.C.; Soltis, S.M.; Abresch, E.; Feher, G. Light-Induced Structural Changes in Photosynthetic Reaction Center: Implications for Mechanism of Electron-Proton Transfer. Science 1997, $276,812$. [CrossRef] [PubMed]

95. Klamt, S.; Grammel, H.; Straube, R.; Ghosh, R.; Gilles, E.D. Modeling the electron transport chain of purple non-sulfur bacteria. Mol. Syst. Biol. 2008, 4, 156. [CrossRef] [PubMed]

96. Steinberg-Yfrach, G.; Liddell, P.A.; Hung, S.-C.; Moore, A.L.; Gust, D.; Moore, T.A. Conversion of light energy to proton potential in liposomes by artificial photosynthetic reaction centres. Nature 1997, 385, 239. [CrossRef]

97. Einfalt, T.; Witzigmann, D.; Edlinger, C.; Sieber, S.; Goers, R.; Najer, A.; Spulber, M.; Onaca-Fischer, O.; Huwyler, J.; Palivan, C.G. Biomimetic artificial organelles with in vitro and in vivo activity triggered by reduction in microenvironment. Nat. Commun. 2018, 9, 1127. [CrossRef]

98. Dai, L.; Tan, L.-M.; Jiang, Y.-L.; Shi, Y.; Wang, P.; Zhang, J.-P.; Otomo, Z.-Y. Orientation assignment of LH2 and LH1-RC complexes from Thermochromatium tepidum reconstituted in PC liposome and their ultrafast excitation dynamics comparison between in artificial and in natural chromatophores. Chem. Phys. Lett. 2018, 705, 78-84. [CrossRef]

99. Nagy, L.; Milano, F.; Dorogi, M.; Agostiano, A.; Laczkó, G.; Szebényi, K.; Váró, G.; Trotta, M.; Maróti, P. Protein/Lipid Interaction in the Bacterial Photosynthetic Reaction Center: Phosphatidylcholine and Phosphatidylglycerol Modify the Free Energy Levels of the Quinones. Biochemistry 2004, 43, 12913-12923. [CrossRef]

100. Trotta, M.; Milano, F.; Nagy, L.; Agostiano, A. Response of membrane protein to the environment: the case of photosynthetic Reaction Centre. Mater. Sci. Eng. C 2002, 22, 263-267. [CrossRef]

101. Palazzo, G.; Mallardi, A.; Giustini, M.; Berti, D.; Venturoli, G. Cumulant Analysis of Charge Recombination Kinetics in Bacterial Reaction Centers Reconstituted into Lipid Vesicles. Biophys. J. 2000, 79, 1171-1179. [CrossRef]

102. Baciou, L.; Rivas, E.; Sebban, P. P+QA - and P+QB- charge recombinations in Rhodopseudomonas viridis chromatophores and in reaction centers reconstituted in phosphatidylcholine liposomes. Existence of two conformational states of the reaction centers and effects of $\mathrm{pH}$ and o-phenanthroline. Biochemistry 1990, 29, 2966-2976. [CrossRef] [PubMed]

103. Overfield, R.E.; Wraight, C.A. Oxidation of cytochromes $\mathrm{c}$ and $\mathrm{c} 2$ by bacterial photosynthetic reaction centers in phospholipid vesicles. 1. Studies with neutral membranes. Biochemistry 1980, 19, 3322-3327. [CrossRef] [PubMed] 
104. Allen, J.P.; Feher, G.; Yeates, T.O.; Komiya, H.; Rees, D.C. Structure of the reaction center from Rhodobacter sphaeroides R-26: protein-cofactor (quinones and Fe2+) interactions. Proc. Natl. Acad. Sci. USA 1988, 85, 8487-8491. [CrossRef] [PubMed]

105. Hellingwerf, K.J. Reaction centers fromRhodopseudomonas sphaeroides in reconstituted phospholipid vesicles. I. Structural studies. J. Bioenerg. Biomembr. 1987, 19, 203-223. [CrossRef] [PubMed]

106. Hara, M.; Ueno, T.; Fujii, T.; Yang, Q.; Asada, Y.; Miyake, J. Orientation of Photosynthetic Reaction Center Reconstituted in Neutral and Charged Liposomes. Biosci. Biotechnol. Biochem. 1997, 61, 1577-1579. [CrossRef]

107. Yanagisawa, M.; Iwamoto, M.; Kato, A.; Yoshikawa, K.; Oiki, S. Oriented Reconstitution of a Membrane Protein in a Giant Unilamellar Vesicle: Experimental Verification with the Potassium Channel KcsA. J. Am. Chem. Soc. 2011, 133, 11774-11779. [CrossRef] [PubMed]

108. Liang, H.; Whited, G.; Nguyen, C.; Stucky, G.D. The directed cooperative assembly of proteorhodopsin into 2D and 3D polarized arrays. Proc. Natl. Acad. Sci. USA 2007, 104, 8212-8217. [CrossRef]

109. Luo, L.; Eisenberg, A. Thermodynamic Size Control of Block Copolymer Vesicles in Solution. Langmuir 2001, 17, 6804-6811. [CrossRef]

110. Luo, L.; Eisenberg, A. Thermodynamic Stabilization Mechanism of Block Copolymer Vesicles. J. Am. Chem. Soc. 2001, 123, 1012-1013. [CrossRef]

111. Zhang, Y.; Wu, F.; Yuan, W.; Jin, T. Polymersomes of asymmetric bilayer membrane formed by phase-guided assembly. J. Controlled Release 2010, 147, 413-419. [CrossRef] [PubMed]

112. Mason, A.F.; Thordarson, P. Polymersomes as protocellular constructs. J. Polym. Sci., Part A: Polym. Chem. 2017, 55, 3817-3825. [CrossRef]

113. Stoenescu, R.; Graff, A.; Meier, W. Asymmetric ABC-triblock copolymer membranes induce a directed insertion of membrane proteins. Macromol. Biosci. 2004, 4, 930-935. [CrossRef] [PubMed]

114. Romsicki, Y.; Sharom, F.J. Phospholipid flippase activity of the reconstituted P-glycoprotein multidrug transporter. Biochemistry 2001, 40, 6937-6947. [CrossRef] [PubMed]

115. Pfleger, N.; Wörner, A.C.; Yang, J.; Shastri, S.; Hellmich, U.A.; Aslimovska, L.; Maier, M.S.M.; Glaubitz, C. Solid-state NMR and functional studies on proteorhodopsin. Biochim. Biophys. Acta Bioenerg. 2009, 1787, 697-705. [CrossRef] [PubMed]

116. Uchihashi, T.; Iino, R.; Ando, T.; Noji, H. High-Speed Atomic Force Microscopy Reveals Rotary Catalysis of Rotorless $F_{1}$-ATPase. Science 2011, 333, 755-758. [CrossRef] [PubMed]

117. Stock, D.; Leslie, A.G.W.; Walker, J.E. Molecular Architecture of the Rotary Motor in ATP Synthase. Science 1999, 286, 1700-1705. [CrossRef]

118. Boyer, P.D. The ATP Synthase-A Splendid Molecular Machine. Ann. Rev. Biochem. 1997, 66, 717-749. [CrossRef]

119. Luo, T.-J.M.; Soong, R.; Lan, E.; Dunn, B.; Montemagno, C. Photo-induced proton gradients and ATP biosynthesis produced by vesicles encapsulated in a silica matrix. Nat. Mater. 2005, 4, 220-224. [CrossRef]

120. Duan, L.; He, Q.; Wang, K.; Yan, X.; Cui, Y.; Möhwald, H.; Li, J. Adenosine Triphosphate Biosynthesis Catalyzed by FoF1 ATP Synthase Assembled in Polymer Microcapsules. Angew. Chem. 2007, 119, 7126-7130. [CrossRef]

121. Qi, W.; Duan, L.; Wang, K.W.; Yan, X.H.; Cui, Y.; He, Q.; Li, J. Motor Protein CF0F1 Reconstituted in Lipid-Coated Hemoglobin Microcapsules for ATP Synthesis. Adv. Mater. 2008, 20, 601-605. [CrossRef]

122. Li, J.-H.; Wang, Y.-F.; Ha, W.; Liu, Y.; Ding, L.-S.; Li, B.-J.; Zhang, S. Cyclodextrin-Based Microcapsules as Bioreactors for ATP Biosynthesis. Biomacromolecules 2013, 14, 2984-2988. [CrossRef] [PubMed]

123. Umena, Y.; Kawakami, K.; Shen, J.-R.; Kamiya, N. Crystal structure of oxygen-evolving photosystem II at a resolution of $1.9 \AA ̊$. Nature 2011, 473, 55. [CrossRef] [PubMed]

124. Andreiadis, E.S.; Chavarot-Kerlidou, M.; Fontecave, M.; Artero, V. Artificial Photosynthesis: From Molecular Catalysts for Light-driven Water Splitting to Photoelectrochemical Cells. Photochem. Photobiol. 2011, 87, $946-964$. [CrossRef] [PubMed]

125. Petrov, A.I.; Volodkin, D.V.; Sukhorukov, G.B. Protein-Calcium Carbonate Coprecipitation: A Tool for Protein Encapsulation. Biotechnol. Progr. 2008, 21, 918-925. [CrossRef] [PubMed]

126. Klermund, L.; Castiglione, K. Polymersomes as nanoreactors for preparative biocatalytic applications: current challenges and future perspectives. Bioprocess. Biosyst. Eng. 2018, 41, 1233-1246. [CrossRef] [PubMed]

127. Michel, H. Editorial: The Nonsense of Biofules. Angew. Chem. Int. Ed. 2012, 51, 2516-2518. [CrossRef] 
128. Dimroth, F.; Roesener, T.; Essig, S.; Weuffen, C.; Wekkeli, A.; Oliva, E.; Siefer, G.; Volz, K.; Hannappel, T.; Häussler, D.; et al. Comparison of Direct Growth and Wafer Bonding for the Fabrication of GaInP/GaAs Dual-Junction Solar Cells on Silicon. IEEE J. Photovoltaics 2014, 4, 620-625. [CrossRef]

129. Hall, D.; Rao, K. Photosynthesis, 6th ed.; Cambridge University Press: Cambridge, UK, 1999.

(c) 2018 by the authors. Licensee MDPI, Basel, Switzerland. This article is an open access article distributed under the terms and conditions of the Creative Commons Attribution (CC BY) license (http:/ / creativecommons.org/licenses/by/4.0/). 